\title{
De houdbaarheidsdatum van ons pensioenstelstel
}

Citation for published version (APA):

Kleynen, R. (2002). De houdbaarheidsdatum van ons pensioenstelstel. Universiteit Maastricht. https://doi.org/10.26481/spe.20021115rk

Document status and date:

Published: 15/11/2002

DOI:

10.26481/spe.20021115rk

Document Version:

Publisher's PDF, also known as Version of record

\section{Please check the document version of this publication:}

- A submitted manuscript is the version of the article upon submission and before peer-review. There can be important differences between the submitted version and the official published version of record.

People interested in the research are advised to contact the author for the final version of the publication, or visit the DOI to the publisher's website.

- The final author version and the galley proof are versions of the publication after peer review.

- The final published version features the final layout of the paper including the volume, issue and page numbers.

Link to publication

\footnotetext{
General rights rights.

- You may freely distribute the URL identifying the publication in the public portal. please follow below link for the End User Agreement:

www.umlib.nl/taverne-license

Take down policy

If you believe that this document breaches copyright please contact us at:

repository@maastrichtuniversity.nl

providing details and we will investigate your claim.
}

Copyright and moral rights for the publications made accessible in the public portal are retained by the authors and/or other copyright owners and it is a condition of accessing publications that users recognise and abide by the legal requirements associated with these

- Users may download and print one copy of any publication from the public portal for the purpose of private study or research.

- You may not further distribute the material or use it for any profit-making activity or commercial gain

If the publication is distributed under the terms of Article $25 \mathrm{fa}$ of the Dutch Copyright Act, indicated by the "Taverne" license above, 
HCl

(ros 
De houdbaarheidsdatum van ons pensioenstelsel 



\section{De houdbaarheidsdatum van ons pensioenstelsel}

Rede in verkorte vorm uitgesproken bij de aanvaarding van het ambt van hoogleraar Actuariële Wetenschappen, specialisatie Asset Liability Management aan de Universiteit Maastricht op vrijdag 15 november 2002 door

Dr. R.H.M.A. Kleynen AAG 


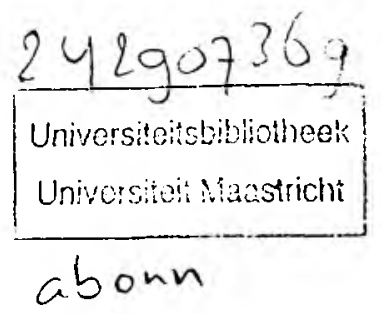

Uitgever: Kleynen Consultants bv te Heerlen

Omslagontwerp: Marcel van der Heyden te Heerlen

ISBN 90-807493-1-1

(C) R.H.M.A. Kleynen, 2002

Alle rechten voorbehouden. Niets van deze uitgave mag worden verveelvoudigd, opgeslagen in een geautomatiseerd gegevensbestand, of openbaar gemaakt, in enige vorm of op enige wijze, hetzij elektronisch, mechanisch, door fotokopieën, opnamen, of enige andere manier, zonder voorafgaande schriftelijke toestemming van Kleynen Consultants bv. 
Inhoudsopgave

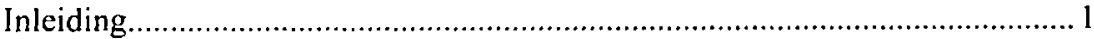

Het pensioenstelsel in een historisch perspectief ........................................... 1

Vermogensontwikkeling en portefeuillesamenstelling: een terugblik............... 4

De historische ontwikkeling van vermogensmarkten ................................... 6

Het huidige financiële fundament van pensioenfondsen nader beschouwd ..... 10

Opgebouwde rechten: wat zijn dat? ............................................................... 11

Hoe te komen tot toekomstige cashflows? ................................................. 11

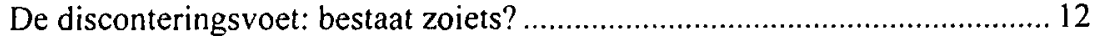

Naar een transparante waardering: de marktwaarde ....................................... 13

Een integrale aanpak: Asset Liability Management ...................................... 16

Het formuleren van toekomstscenario's ..................................................... 17

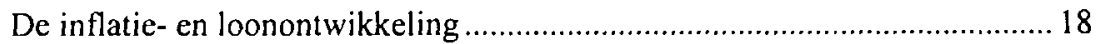

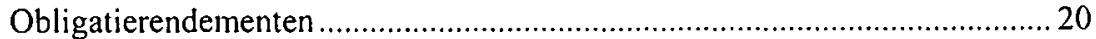

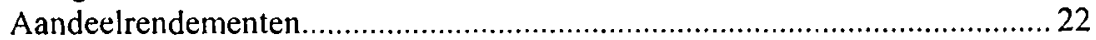

Het huidige tijdsgewricht en de houdbaarheidsdatum van ons

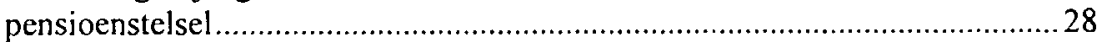

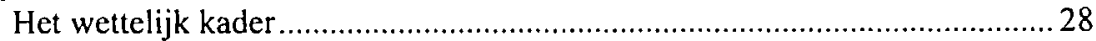

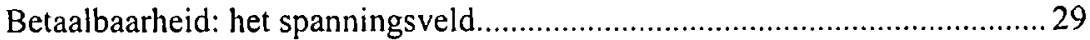

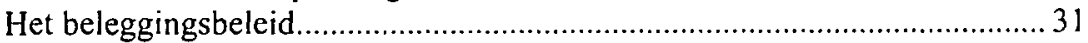

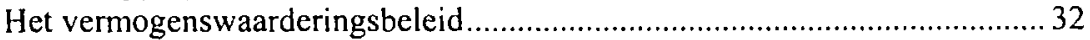

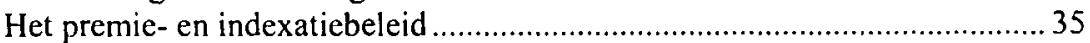

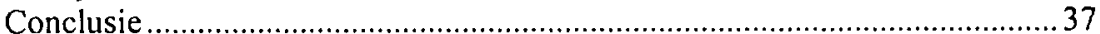

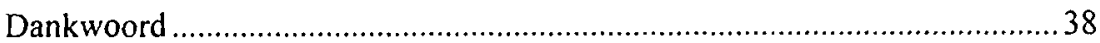

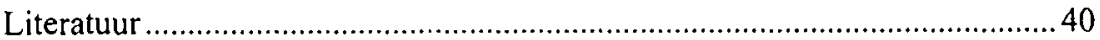


Tabellen

Tabel 1 De omvang en samenstelling van het belegd vermogen van de Nederlandse pensioenfondsen (in \%)............................................. 4

Tabel 2 De ontwikkeling van de dekkingsgraad: periode 1996-2000 (in \%)....5

Tabel 3 De ontwikkeling van de Nederlandse vermogensmarkt in nominale termen, periode 1900-2000 (in \%) .................................................. 7

Tabel 4 De ontwikkeling van de Nederlandse vermogensmarkt in reële termen, periode 1900-2000 (in \%) ............................................. 8

Tabel 5 De ontwikkeling van de risicopremie voor de Nederlandse markt, periode 1900-2000 (in \%) ......................................................... 9

Tabel 6 De ontwikkeling van de wereld vermogensmarkt, periode 1900 2000 (in \%)

Tabel 7 De ontwikkeling van de reserve bij verschillende veronderstellingen ten aanzien van het sterfteverloop

Tabel 8 De omvang van de reserve bij verschillende veronderstellingen ten aanzien van de rekenrente

Tabel 9 Een mogelijk toekomstscenario 25

Tabel 10 Overzicht van de reële ontwikkeling van rendementen en van de inflatie voor de Nederlandse markt over de periode 1900-2000 26

Tabel 11 Overzicht van de reële ontwikkeling van rendementen en van de inflatie voor de wereldmarkt over de periode 1900-2000

Figuren

Figuur 1 De ontwikkeling van de Nederlandse inflatie: periode 1971-2001 _.... 18

Figuur 2 De Nederlandse loonontwikkeling: periode 1946-2001 ...................... 19

Figuur 3 De Nederlandse gecumuleerde prijs- en loonontwikkeling: periode

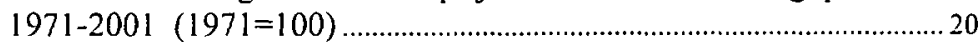

Figuur 4 De Nederlandse lange rente: periode 1978-2002 ……........................21

Figuur 5 De Nederlandse obligatiemarkt: periode 1980-2002 …........................ 21

Figuur 6 De Nederlandse aandelenmarkt: periode 1970-2002 ….......................... 23

Figuur 7 Het spanningsveld bij de bepaling van de premievoet............................29

Figuur 8 De opzet van het financiële kader ................................................................. 33 


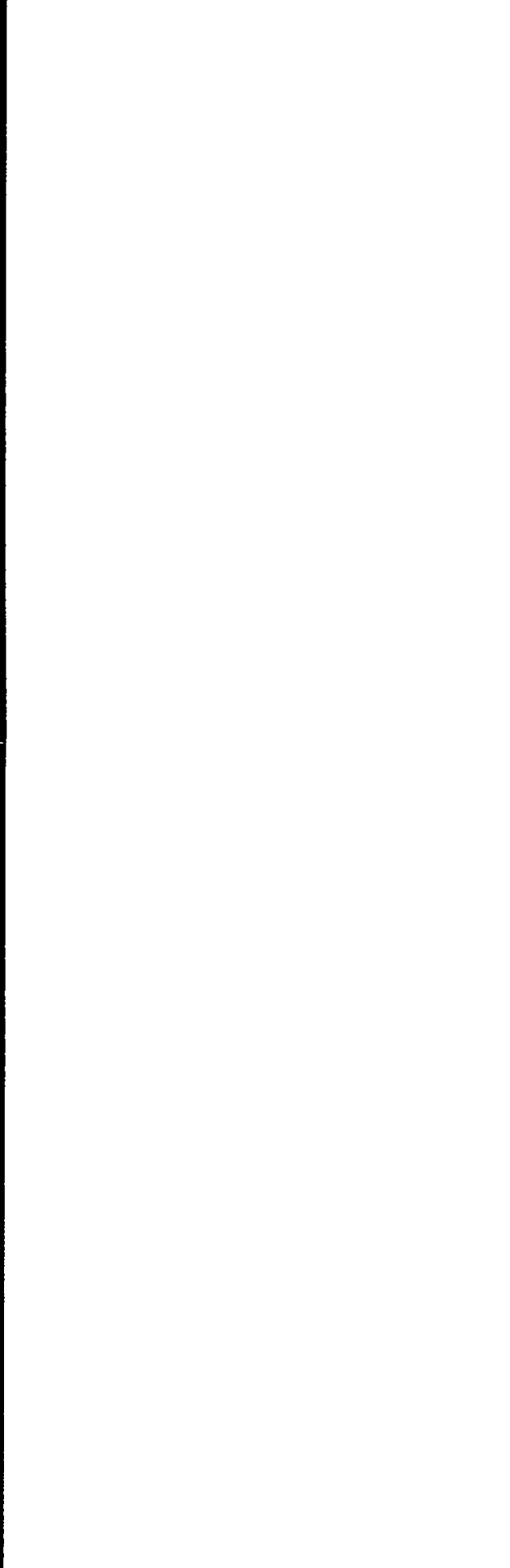


Mijnheer de Rector Magnificus, Zeer geachte dames en heren,

\section{Inleiding}

De houdbaarheidsdatum van ons pensioenstelsel, dat is het onderwerp waar ik vanmiddag graag nader op in wil gaan. Zes jaar en twee weken geleden mocht ik een soortgelijk onderwerp aansnijden. Dat was tijdens de verdediging van mijn proefschrift Asset Liability Management binnen Pensioenfondsen aan de Katholieke Universiteit Tilburg. In die tijd leken aandeelkoersen alleen nog maar te kunnen stijgen en was de houdbaarheidsdatum van ons pensioenstelsel niet echt onderwerp van gesprek. Mijn stelling toentertijd dat toepassing van voorwaardelijke indexatie van pensioenen van primair belang was voor het betaalbaar houden van salarisgekoppelde pensioenregelingen werd met enige scepsis ontvangen. Tegenwoordig is een ieder zich van de relevantie hiervan bewust. Nu de dekkingsgraad' van een groot aantal pensioenfondsen in de buurt van de $100 \%$ komt of zelfs daaronder rijst de vraag of pensioenfondsen in de gevarenzone zitten of dat het allemaal wel meevalt. Een nadere evaluatie van het door de actuaris gehanteerde stelsel van uitgangspunten kan in een dergelijke situatie dan ook geen kwaad. Na deze evaluatie kan de vraag beantwoord worden of de houdbaarheidsdatum in de nabije toekomst ligt of wellicht toch verder naar de toekomst kan worden doorgeschoven. Alvorens dit onderwerp aan te snijden wil ik graag een uitstapje naar de historie van ons pensioenstelsel maken. Niet om u een uitputtend relaas te geven van die historie, maar om de achtergronden die hebben geleid tot de huidige pensioenconstellatie nader uiteen te zetten ${ }^{2}$.

\section{Het pensioenstelsel in een historisch perspectief}

De historie voor wat betreft het Nederlandse pensioenstelsel begint rond 1800 . Lange tijd huldigde men de opvatting dat de zorg voor pensioen een verantwoordelijkheid van de werknemer zelf was. De gedachte was dat de arbeider "de zedelijke plicht" had zelf voor zijn toekomst te zorgen en zijn lasten niet op anderen af te wentelen. Deze opvatting veranderde aan het begin van de 20 -ste

\footnotetext{
${ }^{1}$ Een dekkingsgraad van $100 \%$ impliceert dat de gereservecrde gelden exact overeenkomen met de aanwezige middelen. Een dekkingsgraad groter dan $100 \%$ houdt in dat er meer vermogen aanwezig is dan dat er aan berckende voorzieningen zijn. Deze dekkingsgraad zou een indicator voor de solvabiliteit kunnen zijn. Een pensioenfonds is solvabel als het ook op de lange termijn aan zijn verplichtingen kan voldoen.

Zie voor cen uitgebreid historisch overzicht van de ontwikkeling van pensioenen Hertogh (1992)
} 
eeuw. Vanaf dat moment werd het standpunt gehuldigd dat het in strijd met het rechtsbesef was dat "een arbeider, die gearbeid had zolang hij kan, op het ogenblik dat hij niet meer kan werken, aangewezen is op onderstand van derden". Over het niveau van de in die periode geïnitieerde pensioenregelingen dient men echter niet veel illusies te hebben. Veel ouderen verkeerden nog steeds in behoeftige omstandigheden en de armenzorg was nog steeds niet overbodig.

$\mathrm{Na}$ de Tweede Wereldoorlog ontstond er een zeer nijpende situatie hetgeen leidde tot een wijziging van het sociale zekerheidsstelsel. Het was in deze tijd dat Drees de befaamde Noodwet Ouderdomsvoorziening aan de kamer voorlegde. Een wet die in 1947 in werking trad en de voorloper van de Algemene Ouderdomswet (AOW) was. Het recht dat een werknemer in die tijd had op ouderdomspensioen was danig ingeperkt in die zin dat veelal een voorwaarde voor pensioentoekenning was dat de werknemer de onderneming pas op de pensioengerechtigde leeftijd verliet. Veranderde men voortijdig van werkgever, dan verspeelde men zijn pensioenrechten. Dit aspect en de financiële debacles, voortkomend uit het feit dat de pensioenvermogens binnen de onderneming in eigen beheer werden gehouden en daarmee werden blootgesteld aan ondernemingsrisico, leidden tot de invoering van de Pensioen- en Spaarfondsenwet (PSW) in 1952. Deze PSW regelde in hoofdzaak twee onderwerpen namelijk de financiële veiligstelling buiten de onderneming van de toegezegde pensioenaanspraken en de handhaving van de verworven rechten, hetgeen onder andere bewerkstelligd werd door het onder toezicht van de Pensioen- \& Verzekeringskamer (PVK) stellen van pensioenfondsen. Tegen het eind van de jaren vijftig in de vorige eeuw was er in Nederland alom tevredenheid over de systematiek van de wettelijke en aanvullende pensioenregelingen.

Aan het einde van de jaren zestig - de geleide loonpolitiek was toen al geruime tijd losgelaten - leidde de jaarlijkse hoge stijging van de kosten van levensonderhoud ertoe dat veel gepensioneerden bij pensionering een inkomen bleken te ontvangen dat minder dan de helft van hun laatst genoten salaris bedroeg. Voor een grote groep kon dit nog enigszins opgevangen worden door de koppeling tussen de AOW en het wettelijk minimumloon.

Om meer structuur en zekerheid in de pensioenregelingen te krijgen, werden in de jaren zeventig vele studies verricht, onder andere naar pensioenbreuk, waardevastheid, pensioenplicht en solidariteit. Het is medio jaren zeventig, na de eerste oliecrisis (1973), dat bezuinigingen ten tonele worden gevoerd en ook aan de sociale zekerheid wordt getornd. Rond 1980 doet loonmatiging zijn intrede en zwellen de reserves van pensioenfondsen stevig aan. Het is in deze tijd dat de VUT zijn intrede doet. Het is ook in deze periode dat in het kader van bezuinigingen niet louter maatregelen per sociale regeling werden genomen, maar dat het stelsel van werknemersverzekeringen in zijn geheel werd herzien. Zo werd de Wet op de Arbeidsongeschiktheid (WAO) in zijn geheel grondig aangepast, waarbij de toetredingsmogelijkheden werden beperkt en het uitkeringsniveau 
werd verlaagd. Verder werd de Algemene Weduwen- en Wezenwet (AWW) vervangen door de Algemene nabestaandenwet (Anw). In de nieuwe constellatie werd een inkomenstoets ingevoerd. Inkomsten uit arbeid werden vanaf het moment van invoering gedeeltelijk gekort op de te ontvangen uitkering. Verder doet het kabinet in de jaren negentig een poging tot direct ingrijpen in de opzet van de pensioenregeling door voor afschaffing van het eindloonsysteem en voor invoering van het geïndexeerd middelloonsysteem te pleiten, mede door fiscale faciliëring te beperken tot een middelloonniveau. Om het pensioen beter te laten aansluiten bij het profiel van de werknemer, die was immers lang niet altijd meer de alleenverdienende kostwinnaar, vond het kabinet dat er gekomen moest worden tot een verlaging van de franchise. Uiteindelijk is het niet tot wetgeving gekomen daar het kabinet - na een met sociale partners in een convenant overeengekomen evaluatieperiode van vijf jaar - tot de conclusie was gekomen dat er voldoende regulering vanuit sociale partners zelf was gekomen. Wetgeving was dan ook niet meer nodig ${ }^{3}$. Rond de eeuwwisseling werd ook een begin gemaakt met de transformatie van de VUT-regelingen naar prepensioenregelingen. De VUT bleek een zeer kostbare regeling te zijn. De regeling kende veel meer deelnemers dan verwacht en de hiermee gepaard gaande kosten namen dermate toe dat men tot de conclusie kwam dat een dergelijke regeling op termijn niet te handhaven viel. Verder is er een transformatie van de aard van het pensioensysteem waar te nemen. Deze transformatie betreft met name een overgang van de traditionele eindloonregeling naar een geïndexeerde middelloonregeling. Veelal leeft de gedachte dat een dergelijke transformatie het karakter heeft van een bezuinigingsoperatie. In de praktijk is evenwel waar te nemen dat actuariële neutraliteit, dat wil zeggen dat de benodigde reserves in omvang niet dienen te wijzigen, wordt nagestreefd. Een mutatie van het pensioensysteem leidt in een dergelijke situatie dan ook tot inkomensverschuiving, al naar gelang de verschillende ingrepen in de systematiek. Aanpassingen die veelal gepleegd worden betreffen het jaarlijkse opbouwpercentage dat wordt verhoogd en verlaging van de franchise ${ }^{4}$, het bedrag waarover geen pensioen wordt opgebouwd. Verder dienen als gevolg van het nieuwe tijdsgewricht zaken als uitruil van ouderdomspensioen en nabestaandenpensioen ${ }^{5}$ alsmede de keuze van het moment van pensionering en van de hoogte van het pensioen binnen de pensioenregeling te worden opgenomen.

Uit het vorenstaande kan worden geconcludeerd dat de pensioenregeling met name in de vorige eeuw zijn fundamenten kent. Verder valt op dat - daar waar voor de Tweede Wereldoorlog het niveau van de regeling nog weinig om het lijf had - rond 1970 de basis van de pensioenregelingen zoals we die thans kennen

\footnotetext{
${ }^{3}$ Frappant in dezen is dat de overheid zelf nog steeds een eindloonregeling kent.

${ }^{4}$ Deze franchise kent in sommige gevallen een directe koppeling met de AOW (circa $20 \%$ van alle regelingen). maar is veelal gelijk gesteld an een vast geìndexecrd bedrag (circa $65 \%$ van alle regelingen) (7ie PVK (2002)).

${ }_{5}^{5} \mathrm{Er}$ is alleen sprake van de mogelijkheid tot uitruil indien het nabestaandenpensioen niet op risicobasis verzekerd is.
} 
werd gelegd. Vervolgens waren het vooral bezuinigingen binnen de sociale zekerheid die aan de onderzijde het pensioen dreigden uit te hollen. Hazeu (1998) spreekt in dezen over: "De sociale zekerheid viert binnenkort een twijfelachtig jubileum: een kwart eeuw van hervormings- en bezuinigingsmaatregelen".

Pensioenregelingen kennen als basis kapitaaldekking. Dat wil zeggen dat middelen voortvloeiend uit premie-inkomsten en daarop gegenereerde beleggingsopbrengsten voldoende groot dienen te zijn om aan alle uit het pensioenreglement voortvloeiende verplichtingen te voldoen. Dat deze vermogens zeer substantieel zijn blijkt uit de door de Nederlandsche Bank verstrekte gegevens, waaruit valt af te leiden dat ultimo 2001 de Nederlandse pensioenfondsen vermogens aanhielden met een totale waarde van $€ 435$ miljard. Een nadere beschouwing van de samenstelling en historische ontwikkeling van deze vermogens is het onderwerp van de nu volgende paragraaf.

\section{Vermogensontwikkeling en portefeuillesamenstelling: een terugblik}

Pensioenfondsen beschikken over zeer grote vermogens. De wijze waarop deze vermogens ontstaan zijn alsmede het historisch verloop van de omvang en de samenstelling van dit door de Nederlandse pensioenfondsen beheerde vermogen kunnen aan de hand van de onderstaande tabel nader worden beschreven.

Tabel 1 De omvang en samenstelling van het belegd vermogen van de Nederlandse pensioenfondsen (in \%)

\begin{tabular}{|c|c|c|c|c|c|c|c|c|c|c|}
\hline categorie & 1960 & 1965 & 1970 & 1975 & 1980 & 1985 & 1990 & 1995 & 2000 & 2001 \\
\hline kortgeld & 2.6 & 2.9 & 2.1 & 1.8 & 0.9 & 1.5 & 2.3 & 1.9 & 1.7 & 1.6 \\
\hline $\begin{array}{l}\text { obligaties } \\
\text { onderhandse }\end{array}$ & 30.3 & 18.5 & 10.2 & 7.9 & 5.9 & 15.5 & 18.6 & 27.3 & 34.4 & 35.0 \\
\hline $\begin{array}{l}\text { leningen } \\
\text { hypothecaire }\end{array}$ & 53.0 & 60.5 & 67.2 & 71.1 & 77.0 & 62.9 & 50.8 & 31.4 & 6.8 & 5.6 \\
\hline leningen & 5.3 & 5.8 & 4.2 & 3.0 & 3.1 & 4.0 & 4.9 & 4.8 & 2.7 & 2.2 \\
\hline aandelen & 3.5 & 5.1 & 6.1 & 5.9 & 2.8 & 7.0 & 13.9 & 26.4 & 49.0 & 49.9 \\
\hline onroerend goed & 5.2 & 7.3 & 10.3 & 9.8 & 9.7 & 9.1 & 9.4 & 8.1 & 5.4 & 5.7 \\
\hline diverse activa & 0.0 & 0.0 & 0.0 & 0.4 & 0.5 & 0.1 & 0.1 & 0.0 & 0.0 & 0.0 \\
\hline balanstotaal & & & & & & & & & & \\
\hline$(m / n, €)$ & 3.993 & 8.007 & 16,052 & 35,430 & 70.168 & 128.457 & 176.289 & 244,236 & 444,953 & 434,863 \\
\hline
\end{tabular}

Bron: Jaarverslagen van De Nederlandsche Bank, tot en met 1990 tabel 2.2, vanaf 1995 tabel 3.1 statistische bijlage 
Bezien we de ontwikkeling van de samenstelling van de beleggingsportefeuille dan valt een aantal aspecten op. Kortgeld is, zoals verwacht mag worden, slechts zeer beperkt voorhanden. Het relatieve belang van deze beleggingscategorie komt niet boven de $3 \%$ uit. Bij hypothecaire leningen schommelt het relatief belang tussen de $2.2 \%$ en de $5.8 \%$, waarbij moet worden gesteld dat met name in de laatste vijf jaar een forse afname is te zien. Het belang van onderhandse leningen binnen de beleggingsportefeuilles is extreem afgenomen. Daar waar in 1980 de beleggingsportefeuille van pensioenfondsen nog voor bijna $80 \%$ uit deze onderhandse leningen bestond is dit percentage gedaald tot 5.6 in 2001 . Met betrekking tot het relatieve belang in obligaties geldt een geheel ander verloop. In 1960 besloeg deze beleggingscategorie ongeveer $30 \%$ van de beleggingsportefeuille. Vervolgens neemt dit belang af en lijkt zich een verschuiving van obligaties naar onderhandse leningen voor te doen. Het gezamenlijke relatieve belang van deze twee beleggingscategorieën beweegt zich over de periode 1960-1985 rond de $80 \%$. Vanaf 1980 is een steeds verdere toename van het belang in obligaties waar te nemen tot een niveau van $35.0 \%$ in 2001. Het vastgoedbelang ultimo 2001 ligt weer op het niveau van 1960 namelijk rond de $5 \%$. In de periode $1970-1990$ bereikt dit belang een maximum van rond de $10 \%$. De teruggang in het belang van vastgoed in de afgelopen tien jaar hangt mede samen met de wijze waarop vastgoed wordt aangeboden. Daar waar tot 1990 nog sprake was van enkel direct vastgoed, is vanaf medio jaren negentig een tendens waar te nemen van een overgang naar vastgoedaandelen. Deze overgang kan er mede debet aan zijn dat het belang in direct vastgoed afneemt. Bezien we de ontwikkeling van de categorie aandelen, dan valt op dat deze de afgelopen twintig jaar een zeer forse toename laat zien. Daar waar met deze beleggingscategorie in 1980 een vermogensbeslag van nog geen $3 \%$ gemoeid was, gaat met deze beleggingscategorie ultimo 2001 een vermogensbeslag van bijna $50 \%$ gepaard. Uit de bovenstaande tabel kan verder worden afgeleid dat in de periode 1960 tot en met 2001 de pensioenvermogens jaarlijks met ongeveer $12 \%$ zijn toegenomen.

Uit de door de PVK (2002) verstrekte cijfers in de onderstaande tabel kan het verloop van de dekkingsgraad worden afgeleid.

Tabel 2 De ontwikkeling van de dekkingsgraad: periode 1996-2000 (in \%)

\begin{tabular}{|l|c|c|c|c|c|c|}
\hline & 1996 & 1997 & 1998 & 1999 & 2000 & $2001^{\circ}$ \\
\hline dekkingsgraad & 130 & 135 & 142 & 149 & 140 & 126 \\
groei vermogen & & 14.7 & 15.1 & 15.0 & 2.9 & -2.5 \\
\hline
\end{tabular}

prognose op basis van reeds ontvangen staten over 2001

Bron: Pensioen- \& Verzekeringskamer (2002a)

Deze dekkingsgraad is gelijk aan de verhouding van het balanstotaal ten opzichte van de voorziening pensioenverplichtingen. Daar waar de balanspositie 
gedurende de periode 1996-1999 een continue verbetering laat zien, valt als gevolg van de rendementsontwikkeling in 2000 de dekkingsgraad terug van $149 \%$ (ultimo 1999) naar 140\% (ultimo 2000). In 2001 is een verdere terugval te constateren, in die zin dat de dekkingsgraad daalt naar een niveau van $126 \%$. Het moge duidelijk zijn dat de rendementsterugval in 2002, die tot op heden vele malen forser is dan in 2001 , tot een ingrijpende verslechtering van die financiële positie van pensioenfondsen heeft geleid. Dat hierdoor een gemiddeld dekkingsgraadniveau van circa $100 \%$ resulteert lijkt een redelijke schatting.

De forse terugval is - zoals gezegd - een direct gevolg van de rendementsontwikkeling. Uit de PVK-studie Financiële Gegevens Pensioenfondsen 2000 is af te leiden dat daar waar de Nederlandse pensioenfondsen in 1999 nog een gemiddeld beleggingsrendement van $15.0 \%$ wisten te genereren, dit in 2000 slechts $2.6 \%$ bedroeg. Uit de door de WM-company gepubliceerde gegevens over 2001 valt een nieuw dieptepunt vast te stellen met een gemiddeld beleggingsresultaat van $-2.8 \%$. De financiële markten in 2002 laten evenwel een nog veel groter verval zien. De belangrijkste oorzaak van teruglopende rendementen is terug te vinden in de ontwikkeling van de aandelenmarkten. Daar waar in 1999 nog een rendement op aandelen van $29.7 \%$ werd behaald, was dit rendement in 2000 terug gelopen naar $-4.2 \%$. Het gemiddelde rendement op aandelen dat de Nederlandse pensioenfondsen in 2001 realiseerden bedroeg $-14.7 \%$. De enorme terugval van de aandelenmarkten in de eerste negen maanden van 2002 is er de oorzaak van dat het beleggingsrendement over deze periode zwaar negatief is. Uit intern onderzoek van de PVK, uitgevoerd in het eerste kwartaal van 2002 , blijkt dat naar verwachting tien procent van de honderd grootste pensioenfondsen het pensioen in 2002 niet volledig aanpast aan de stijging van de prijzen en de lonen. Binnen deze groep van pensioenfondsen verhoogt één procentpunt de pensioenen in het geheel niet. Dit onderzoek, dat in het eerste kwartaal van dit jaar is uitgevoerd, komt in een nog ander daglicht te staan als men zich realiseert dat de aandeelkoersen sindsdien nog meer weggezakt zijn. Hierdoor wordt een substantieel aantal pensioenfondsen met een dekkingsgraad van rond de $100 \%$ geconfronteerd. De ontwikkeling van vermogensmarkten heeft dus een vergaand effect op de solvabiliteit van pensioenfondsen. Dit is een belangrijke overweging om tot een nadere analyse van de vermogensmarkten over te gaan. Deze analyse is het onderwerp in de nu volgende paragraaf.

\section{De historische ontwikkeling van vermogensmarkten}

Indien we iets zinnigs willen zeggen over de houdbaarheidsdatum van ons pensioenstelsel, dan is het van belang om het gedrag van vermogensmarkten nader te bezien. Het waren tot voor kort immers de winsten die op deze vermogensmarkten werden behaald die een belangrijke bijdrage leverden aan de vorming van de financiële reserves. Bezien we de samenstelling van het belegd 
vermogen, dan kan uit tabel 1 worden afgeleid dat vastrentende waarden en aandelen de belangrijkste beleggingscategorieën vormen. Deze beide beleggingscategorieën leggen een beslag van circa $90 \%$ op de aanwezige fondsen. Het zijn dan ook deze twee beleggingscategorieën die aan een nadere analyse worden onderworpen. Verder is de ontwikkeling van de inflatie een zeer belangrijke grootheid. Deze inflatie is van groot belang daar waar het gaat om indexatie van pensioenen.

De hier gepresenteerde analyse start met een overzicht van de belangrijkste kenmerken van de Nederlandse vermogensmarkt. Vervolgens wordt deze analyse in een internationaal kader gezet. Bezien we de binnenlandse vermogensmarkt dan kan de ontwikkeling aan de hand van de onderstaande tabel worden beschreven.

Tabel 3 De ontwikkeling van de Nederlandse vermogensmarkt in nominale termen, periode 1900-2000 (in \%)

\begin{tabular}{|l|c|c|c|c|c|c|c|}
\hline grootheid & $\begin{array}{c}\text { geometrisch } \\
\text { gemiddelde }\end{array}$ & $\begin{array}{c}\text { rekenkundig } \\
\text { gemiddelde }\end{array}$ & $\begin{array}{c}\text { standaard- } \\
\text { deviatie }\end{array}$ & \multicolumn{2}{|c|}{ laagste waarde } & \multicolumn{2}{|c|}{ hoogste waarde } \\
\hline aandelen & 9.0 & 11.0 & 22.7 & -30.4 & 1932 & 130.1 & 1940 \\
obligaties & 4.1 & 4.4 & 7.6 & -18.5 & 1939 & 36.1 & 1982 \\
inflatie & 3.0 & 3.1 & 5.0 & -13.4 & 1921 & 18.7 & 1918 \\
\hline
\end{tabular}

Bron: Dimson, E., P. March and M. Staunton (2002), tabel 27-I

Uit deze tabel kan worden afgeleid dat het gemiddelde rendement op aandelen over de periode 1900-2000 $9.0 \%$ bedroeg, dit is het zogenaamde geometrische gemiddelde $^{6}$. Indien we het gemiddelde van alle jaarlijkse rendementen nemen resulteert een waarde van $11.0 \%$, hetgeen wordt aangeduid met de term rekenkundig gemiddelde. Voor obligaties kunnen soortgelijke waarden worden afgeleid. Het geometrisch gemiddelde bedraagt $4.1 \%$, het rekenkundige gemiddelde $4.4 \%$. Beide gemiddelden liggen net boven de $4 \%$. Indien we veronderstellen dat ook naar de toekomst toe dit gemiddelde maatgevend is, resulteert - bij een rekenrente van $4 \%$ - slechts een schamele $0.1 \%(0.4 \%)$ aan indexatieruimte. Bezien we de ontwikkeling van de inflatie dan is deze op een geometrische basis gemeten gelijk aan $3.0 \%$, daar waar het rekenkundige gemiddelde gelijk is aan $3.1 \%$. De spreiding rondom deze gemiddelden, een maat voor het risico dat verbonden is aan de betreffende categorie (zie Sortino en Van der Meer (1991)) varieert fors. Aandelen kennen een standaarddeviatie van $22.7 \%$, obligaties van $7.6 \%$ en voor de inflatie geldt een percentage van 5.0 .

\footnotetext{
- Indien we uitgaan van een starvermogen van $€ 100$, een rendement van $+50 \%$ over het eerste jaar en voor het tweede jaar van $-25 \%$, dan resulteert aan het einde van het tweede jaar een vermogen met een waarde van $€$ 112.5. Het feitelijke gemiddelde rendement op jaarbasis is dan gelijk aan $\sqrt{ }(112.5 / 100)-1=0.0607$ oftewel $6.1 \%$. Dit gemiddelde is het geometrische gemiddelde. Het rekenkundige gemiddelde is gelijk an (0.5$0.25) / 2=0.125$ oftewel $12.5 \%$. Met name als waarden fors fluctueren zullen het geometrisch gemiddelde en rekenkundig gemiddelde aanzienlijk verschillen.
} 
Dat ook obligaties fors kunnen variëren valt af te leiden uit de aangegeven maxima en minima in tabel 3. Het laagste rendement bedroeg $-18.5 \%$ en werd behaald in 1939. Het hoogste rendement werd behaald in 1982 en was gelijk aan $36.1 \%$. Extreme inflaties deden zich rond 1920 voor. Daar waar in 1918 nog een inflatie was waar te nemen van $18.7 \%$ sloeg het sentiment in 1921 om, hetgeen resulteerde in een deflatie van $-13.4 \%$. Daar pensioenen veelal een koppeling met de lonen en/of de inflatie kennen is een beschouwing van nominale rendementen weliswaar interessant, maar zijn het met name de reële rendementen die uiteindelijk van belang zijn. Hieromtrent geeft tabel 4 uitsluitsel. De voor inflatie gecorrigeerde rendementcijfers zien er als volgt uit.

Tabel 4 De ontwikkeling van de Nederlandse vermogensmarkt in reële termen, periode 1900-2000 (in \%)

\begin{tabular}{|l|c|c|c|c|c|c|c|}
\hline actief & $\begin{array}{l}\text { geometrisch } \\
\text { gemiddelde }\end{array}$ & $\begin{array}{l}\text { rekenkundig } \\
\text { gemiddelde }\end{array}$ & $\begin{array}{c}\text { standaard- } \\
\text { deviatie }\end{array}$ & \multicolumn{2}{|l|}{ laagste rendement } & \multicolumn{2}{|c|}{ hoogste rendement } \\
\hline aandelen & 5.8 & 7.7 & 21.0 & -34.9 & 1941 & 101.6 & 1940 \\
obligaties & 1.1 & 1.5 & 9.4 & -18.1 & 1915 & 32.8 & 1932 \\
\hline
\end{tabular}

Bron: Dimson, E., P. March and M. Staunton (2002), tabel 27-1

Over de periode van 101 jaar is af te leiden dat aandelen een reëel gemiddeld rendement van $5.8 \%$ gegenereerd hebben (7.7\% rekenkundig). Indien er sprake zou zijn van een prijsgeïndexeerde pensioenregeling en een beleggingsportefeuille die geheel uit aandelen bestaat, dan resulteert gemiddeld bezien een reëel rendement dat ruim boven de $4 \%$ rekenrente ligt. Indien enkel in obligaties zou zijn belegd ontstaat een probleem. Het resulterende reëel rendement is slechts $1.1 \%$ ( $1.5 \%$ rekenkundig) en dat is te beperkt om tegemoet te komen aan de benodigde $4 \%$ rekenrente. Dat houdt dus in dat er ofwel additioneel gefinancierd dient te worden dan wel dat er tot voorwaardelijke indexatie dient te worden overgegaan. Vanuit de optiek van houdbaarheid is het evident dat - indien dit verleden ook maatgevend voor de toekomst zou zijn - beleggingsportefeuilles van pensioenfondsen een aanzienlijk belang in aandelen behoeven. Indien hiertoe niet wordt overgegaan dient óf met een lagere rekenrente gecalculeerd te worden waardoor aanvullende financiering benodigd is of er dient naar verwachting met enige regelmaat voorwaardelijke indexatie te worden toegepast.

Hogere rendementen gaan evenwel normaliter gepaard met hogere risico's. Met andere woorden, het lopen van risico's wordt beloond met een naar verwachting hogere opbrengst. Het verschil in rendement tussen aandelen en vastrentende waarden wordt ook wel aangeduid als de equity risk premium. Deze equity risk premium (de risicopremie) is van groot belang bij het formuleren van toekomstscenario's. Deze premie bepaalt immers in grote mate de aantrekkelijkheid van aandelen ten opzichte van vastrentende waarden. Naast dit verschil in gemiddel- 
de is het uiteraard van groot belang om het verschil in risico tussen beide beleggingscategorieën te beschouwen. Immers, de equity risk premium is de bonus die gepaard gaat met het aanhouden van risicovollere beleggingen. Ook ten aanzien van die risicopremie kan een historisch overzicht worden verkregen, hetgeen er als volgt uitziet.

Tabel 5 De ontwikkeling van de risicopremie voor de Nederlandse markt, periode 1900-2000 (in \%)

\begin{tabular}{|c|c|c|c|c|c|c|c|}
\hline & $\begin{array}{c}\text { geometrisch } \\
\text { gemiddelde }\end{array}$ & $\begin{array}{c}\text { rekenkundig } \\
\text { gemiddelde }\end{array}$ & $\begin{array}{c}\text { standaard- } \\
\text { deviatie }\end{array}$ & \multicolumn{2}{|l|}{ laagste rendement } & \multicolumn{2}{|l|}{ hoogste rendement } \\
\hline risicopremie & 4.7 & 6.7 & 21.4 & -43.9 & 1932 & 107.6 & 1940 \\
\hline
\end{tabular}

Bron: Dimson, E., P. March and M. Staunton (2002), tabel 27-I

Het gemiddelde additionele rendement op aandelen ten opzichte van obligaties, gemeten over de periode $1900-2000$, blijkt gelijk te zijn aan $4.7 \%$ (rekenkundig $6.7 \%$ ). De standaardafwijking, een maat voor de beweeglijkheid van deze grootheid, is echter ook fors met een waarde van $21.4 \%$. Dit impliceert dat er jaren met hoge premies te onderkennen zijn en jaren waarbij risicopremies fors negatief zijn geweest. Ook dat wordt gestaafd door de maximum- c.q. minimumwaarde van de risicopremie.

Bovenstaande tabellen beschouwen de Nederlandse situatie. Beleggen is evenwel een internationale aangelegenheid. Vandaar dat naast de ontwikkelingen op de Nederlandse vermogensmarkt ook een nadere beschouwing van de internationale vermogensmarkt gewenst is. Ook hier maken we gebruik van de studie van Dimson (2002). Op basis van marktgewichten wordt een wereldindex geconstrueerd, waarbij de Verenigde Staten als thuismarkt wordt beschouwd. De gepresenteerde rendementen zijn aldus dollar gerelateerde rendementen.

Tabel 6 De ontwikkeling van de wereld vermogensmarkt, periode 19002000 (in \%)

\begin{tabular}{|l|l|l|c|c|c|c|c|c|}
\hline & actief & $\begin{array}{c}\text { geometrisch } \\
\text { gemiddelde }\end{array}$ & $\begin{array}{c}\text { rekenkundig } \\
\text { gemiddelde }\end{array}$ & $\begin{array}{c}\text { standaard- } \\
\text { deviatie }\end{array}$ & \multicolumn{2}{|c|}{$\begin{array}{c}\text { laagste } \\
\text { waarde }\end{array}$} & \multicolumn{2}{|c|}{$\begin{array}{l}\text { hoogste } \\
\text { waarde }\end{array}$} \\
\hline \multirow{2}{*}{$\begin{array}{l}\text { nominale } \\
\text { rendementen }\end{array}$} & aandelen & 9.2 & 10.4 & 16.5 & -39.2 & 1931 & 71.4 & 1933 \\
\cline { 2 - 10 } & obligaties & 4.4 & 4.7 & 8.5 & -14.4 & 1919 & 34.4 & 1985 \\
\cline { 2 - 10 } & inflatie & 3.2 & 3.3 & 5.0 & -10.8 & 1921 & 20.4 & 1918 \\
\hline \multirow{2}{*}{$\begin{array}{l}\text { reële } \\
\text { rendementen }\end{array}$} & aandelen & 5.8 & 7.2 & 17.0 & -32.8 & 1931 & 70.5 & 1933 \\
\cline { 2 - 9 } & obligaties & 1.2 & 1.7 & 10.3 & -26.6 & 1946 & 31.0 & 1932 \\
\hline risicopremie & aandelen & 4.6 & 5.6 & 14.5 & -31.2 & 1931 & 37.4 & 1958 \\
\hline
\end{tabular}

Bron: Dimson, E., P. March and M. Staunton (2002), tabel 34-1

Bezien we de bovenstaande waarden, dan valt op dat deze waarden qua gemiddelden in het algemeen niet veel verschillen van de overeenkomstige Nederlandse grootheden. Een uitzondering daarop zijn de standaarddeviaties 
voor aandelen, die substantieel lager liggen. Daar waar de Nederlandse aandelenmarkt een standaarddeviatie van $22.7 \%$ kent, is deze voor de wereldmarkt $16.5 \%$, een verschil van meer dan 6\%-punt. Dit verschil vloeit voort uit het feit dat de wereldportefeuille gezien kan worden als de marktportefeuille. Binnen de marktportefeuille is al het niet-systematische risico door diversificatie geëlimineerd. De standaardafwijking van deze marktportefeuille weerspiegelt dan ook uitsluitend het systematische risico. Verder valt af te leiden dat de risicopremie op wereldschaal van $4.6 \%$ (in geometrische termen gemeten) nagenoeg gelijk is aan de overeenkomstige premie in Nederland (4.7\%). Bezien we de rekenkundige gemiddelden dan valt op dat de risicopremie afgeleid voor de wereldnarkt (5.6\%) lager ligt dan voor de Nederlandse markt (6.7\%). Ook hier geldt evenwel weer dat de volatiliteit voor de wereldmarkt $(14.5 \%)$ beduidend lager ligt dan de overeenkomstige waarde voor de Nederlandse markt $(21.4 \%)$.

De gepresenteerde historische uiteenzettingen geven inzicht in het ontstaan van ons pensioenstelsel alsmede de wijze waarop pensioenfondsen zich in het verleden hebben ontwikkeld. Verder worden er enkele ruwe karakteristieken van vermogensmarkten gegeven. Deze beschouwingen lijken retrospectief van aard te zijn. Ze beschrijven immers het verleden. Dit geldt echter niet voor de voorziening pensioenverplichtingen. Aan de waardebepaling van deze voorziening liggen prognoseberekeningen ten grondslag. Als we iets over de houdbaarheidsdatum van ons pensioenstelsel willen zeggen is het allereerst van belang om de fundamenten waarop deze berekening van de voorziening pensioenverplichtingen gebaseerd is nader te beschouwen en te beoordelen. De evaluatie van dit fundament is het onderwerp in de nu volgende paragraaf.

\section{Het huidige financiële fundament van pensioenfondsen nader beschouwd}

In de voorgaande paragraaf stond de historie centraal. In dit hoofdstuk wordt een eerste blik op de toekomst gericht en wordt bezien op welke wijze het fundament van een pensioenfonds kan worden gecreëerd. Daartoe bekijken we de voorziening pensioenverplichtingen (vpv) nader. De vpv is niets meer of minder dan de contante waarde van de verwachte cashflows van toekomstige pensioenbetalingen, voor zover voortvloeiend uit de verplichtingen die op het moment van vaststelling bestaan. Daar zijn we dan gauw mee klaar. Toch niet. De vpv bestaat in deze constellatie uit drie componenten, namelijk uit l) de waarde van de opgebouwde rechten, 2) de hieruit af te leiden toekomstige cashflows en 3) de disconteringsvoet. Deze componenten zullen aan een nadere beschouwing worden onderworpen. Verder dient er uiteraard een kostenopslag op de reserve te 
worden berekend voor toekomstige administratie- en uitkeringskosten. Een vast percentage lijkt daarbij niet vreemd.

\section{Opgebouwde rechten: wat zijn dat?}

Bij de bepaling van de toekomstige cashflows is het huidige opgebouwde pensioenrecht bepalend. De hoogte van dit recht is eenduidig af te leiden uit het gestelde in het pensioenreglement. Daar kan dan ook weinig discussie over zijn. Echter, deze opgebouwde rechten kunnen in de toekomst qua hoogte nog wel degelijk aan verandering onderhevig zijn en wel als gevolg van indexatie. In pensioenregelingen wordt aangegeven op welke wijze men streeft om reeds opgebouwde rechten te indexeren. Dat houdt in dat bij de bepaling van de cashflows deze indexatie zou moeten worden opgenomen. Toekomstige indexaties zijn evenwel niet bekend. Aanvullende uitgangspunten omtrent de hoogte van deze toekomstige indexaties zullen dan ook gedefinieerd dienen te worden. Alvorens over de incorporatie van deze toekomstige indexaties te spreken, wil ik nader ingaan op een andere component die van belang is voor de bepaling van de toekomstige cashflows, namelijk de veronderstellingen die ten aanzien van sterfte worden gemaakt.

\section{Hoe te komen tot toekomstige cashflows?}

Teneinde te komen tot prognoses van cashflows voortvloeiend uit de huidige populatie dienen uitgangspunten te worden geformuleerd omtrent sterfte en afhankelijk van de inhoud van het reglement - omtrent gehuwdheid. Met name in de sterftekansen zien we een ontwikkeling waaraan ontleend kan worden dat de levensverwachting toeneemt. Deze toenemende levensverwachting leidt tot een toename van de benodigde reserves. Maar in welke orde van grootte moet dan gedacht worden? Om hier zicht op te krijgen heb ik gebruik gemaakt van sterftekansen zoals die door het ABP zijn gepubliceerd in wetenschappelijke balansen en grondslagenonderzoeken. Op basis van deze stukken kunnen sterftekansen worden ontleend voor de periode 1922-1993. Hieruit kan worden afgeleid dat de levensverwachting van mannen met een leeftijd van vijfentwintig jaar met ongeveer zeven jaar is toegenomen. Voor vrouwen met diezelfde leeftijd zien we een toename van circa tien jaar. Interessant is het om de hieraan gekoppelde financiële effecten nader te duiden. Hiertoe maken we gebruik van een fictief maar wel representatief geconstrueerd pensioenfonds. Indien we veronderstellen dat de sterftekansen van 1922 als uitgangspunt dienen voor toekomstige prognoses, weten we dat dat een onderschatting van de benodigde reserves tot gevolg heeft. Met de voorhanden zijnde database kunnen we echter de wereld van 1922 tot en met 1993 qua sterfte reconstrueren. Met andere woorden, indien we als uitgangspunt 1922 kiezen kunnen we de feitelijke ontwikkeling voor de komende zeventig jaar nabootsen en bezien wat gegeven deze feitelijke 
ontwikkeling van de sterftekansen de reserve ultimo 1922 in werkelijkheid had moeten zijn. Doen we dat op basis van het gefingeerde pensioenfonds, dan leidt dat tot de volgende resultaten.

Tabel 7 De ontwikkeling van de reserve bij verschillende veronderstellingen ten aanzien van het sterfteverloop

\begin{tabular}{|l|c|}
\hline basis & reserve \\
\hline 1922 & 100 \\
1935 & 105 \\
1948 & 109 \\
1961 & 112 \\
1974 & 113 \\
1993 & 119 \\
$1922-1993$ & 106 \\
\hline
\end{tabular}

Uit de bovenstaande tabel kan worden afgeleid dat het effect van een overschatting van de sterftekansen in de orde van grootte van 6\% ligt. Met andere woorden, de in 1922 berekende reserve zou vanuit de optiek van een correcte sterftebepaling een opslag van $6 \%$ moeten krijgen. Verder zien we dat de jaarlijkse stijging van de reserve gemeten over de periode 1922 tot en met 1993 in de orde van grootte van $2.5 \%$ ligt.

De bepaling van de opgebouwde rechten reserve bestaat uit twee pijlers. Enerzijds dienen er veronderstellingen gemaakt te worden met betrekking tot sterftekansen, anderzijds dienen disconteringsvoeten te worden bepaald. Dit laatste aspect krijgt in de nu volgende paragraaf de aandacht.

\section{De disconteringsvoet: bestaat zoiets?}

Teneinde de benodigde reserve te kunnen bepalen dienen de prognoses ten aanzien van de cashflows verdisconteerd te worden. Traditioneel gebruiken we daar een vaste rentevoet voor die gelijk is aan $4 \%$. Deze vaste $4 \%$-rente wordt ook wel de rekenrente genoemd. Hoger mag niet van de toezichthouder, de PVK, en een lagere vaststelling van de rekenrente leidt tot een stijging van de benodigde reserves zodat het enthousiasme daarvoor niet echt groot is. Maar klopt die 4\%rekenrente wel, of anders gesteld, wat is de filosofie achter deze rekenrente. Indien men uitgaat van niet geïndexeerde verplichtingen zou men kunnen stellen dat een dergelijke rente altijd wel gehaald zou kunnen worden. Maar zelfs deze redenering kan, met name bij kort lopende contracten - denk daarbij aan prepensioenuitkeringen - mank gaan. Voor lang lopende contracten is een dergelijk percentage - met de huidige rentestanden - niet onredelijk als we ervan uitgaan dat toekomstige indexaties de sluitpost vormen. Dit impliceert dat ieder jaar een separate beslissing dient te worden genomen omtrent de grootte van de te geven pensioenindexatie. Deze handelswijze ligt geheel in lijn met de wijze 
waarop in Nederland met pensioenindexatie wordt omgegaan. Indexatie is de sluitpost van het geheel. Dat houdt dan natuurlijk ook in dat indien de middelen niet toereikend zijn het een logische stap is om over te gaan tot voorwaardelijke indexatie, dan wel de indexatie geheel achterwege te laten.

De rekenrente is een essentiële grootheid in het kader van de bepaling van de vpv. Pensioenfondsen met een prijsgekoppelde regeling gebruiken veelal een rekenrente van $4 \%$, pensioenfondsen met een koppeling op basis van de loonontwikkeling hanteren normaliter $4 \%$ en pensioenfondsen waarbinnen geen indexatie verstrekt wordt gaan ook vaak van $4 \%$ uit. Dat oogt niet alleen vreemd, dat is ook vreemd. Pensioenfondsen dienen expliciet aan te geven wat hun ambitie ten aanzien van de regeling is. Op basis van dat ambitieniveau kan vervolgens bepaald worden wat de werkelijke waarde van de verplichtingen is en daarmee de waarde van de benodigde vpv. De vraag die aan de orde is, is dus wat de werkelijke waarde - de fair value - van de verplichtingen is. Nog scherper gesteld: wat is de marktwaarde van de verplichtingen. Welke disconteringsvoet moet er gehanteerd worden en is die disconteringsvoet afhankelijk van de beleggingen, bijvoorbeeld als we veel in aandelen beleggen kunnen we dan met een hoger rendement verdisconteren dan wanneer alle middelen in obligaties zouden zijn belegd? Of is de disconteringsvoet onafhankelijk van de samenstelling van de beleggingsportefeuille? Maar speelt de samenstelling van de beleggingsportefeuille dan helemaal geen rol? In een compleet model van marktwaardewaardering dient op al deze vragen een antwoord te worden gegeven. Het concept dat hierbij gehanteerd wordt, is dermate belangrijk dat $\mathrm{ik}$ daar de volgende paragraaf uit mijn betoog aan wil wijden.

\section{Naar een transparante waardering: de marktwaarde}

Briys en De Varenne (1997) beschrijven het theoretisch kader waarbinnen marktwaardewaardering van pensioenverplichtingen vorm kan worden gegeven. Ofschoon het door hen beschreven model eenvoudig van opzet is, beschrijft het de essentie van marktwaardewaardering in detail. De contante waarde van de verplichtingen wordt in dit model bepaald met behulp van een rente termijn structuurmodel, de zogenaamde zero coupon curve. Het op een andere wijze prijzen van deze verplichtingen in een liquide markt zou mogelijkheden bieden tot arbitrage (zie Cairns (2001)). Onder arbitrage wordt verstaan het feit dat als gevolg van een foutieve prijsstelling risicovrije winsten kunnen worden behaald. Het betreft hier het gelijktijdig kopen en verkopen van equivalente beleggingen om zodoende te profiteren van discrepanties in hun onderlinge prijzen (zie Bodie, Kane and Marcus (1996)). Indien alleen de zero coupon curve een rol speelt bij de waardering van de verplichtingen impliceert dat dat er geen link zou bestaan tussen de aangegane verplichtingen enerzijds en de samenstelling van de 
beleggingsportefeuille anderzijds. Edoch, deze relatie is wel degelijk te onderkennen en vloeit voort uit de risico's die voortkomen uit de samenstelling van de feitelijke beleggingsportefeuille. Een zwaar risicovolle portefeuille mag dan wel een hoog verwacht rendement opleveren, het feit dat er ook zware negatieve rendementen uit voort kunnen vloeien impliceert dat er ook mogelijke momenten zijn dat slechts deels of - in het ergste geval - in het geheel niet aan de verplichtingen kan worden voldaan. De huidige tijden van zwaar negatieve aandeelrendementen zijn een sprekend voorbeeld van de beïnvloeding van de portefeuillesamenstelling op de waarde van de aangegane verplichtingen. Dit geheel van risico's kan in een raamwerk van een tweetal opties worden weergegeven. Vanuit de optiek van de deelnemer van een pensioenfonds hangt de eerste component samen met het feit dat - als gevolg van de feitelijke samenstelling van de beleggingsportefeuille - men het risico loopt om slechts een gedeelte van de verwachte uitkering te ontvangen. Dit is te vergelijken met een situatie waarin de betreffende deelnemer een put optie heeft verkocht. De tweede component betreft mogelijke winstuitkeringen als gevolg van het bovenmatig presteren van de beleggingsportefeuille. In dit geval is vanuit de optiek van de deelnemer sprake van een gekochte call optie. Vanuit risico-optiek is de waardeontwikkeling van de geschreven put optie relevant. Neemt deze waarde toe, dan daalt de marktwaarde van de verplichtingen. Dit impliceert dat de kans dat uiteindelijk het pensioen de hoogte heeft die men verwacht, afneemt. Aan de andere kant, als er forse rendementen worden geboekt, neemt de kans op toeslagen toe.

Laten we nog even bij het onderwerp marktwaarde stilstaan. Binnen deze marktwaardewaardering staat de vigerende zero coupon curve centraal. Een vrij grove benadering voor die vigerende rentecurve zou - bezien de ontwikkeling van deze rentecurve en de looptijd van de verplichtingen - een vaste rentevoet in de orde van grootte van $5.5 \%$ kunnen zijn. Dan is er evenwel geen rekening gehouden met toekomstige indexaties. Het opnemen van deze indexaties kan op twee manieren. Enerzijds door verwachte toekomstige uitkeringen op te hogen met een geschat inflatiepercentage of anderzijds door niet van een nominale rentecurve uit te gaan, maar van een reële rentetermijnstructuur. Een reële rentetermijnstructuur impliceert dat er een correctie op de nominale rentetermijnstructuur wordt uitgevoerd overeenkomstig de aard van de indexatie. Bij een loongekoppelde regeling zou dat de loonverwachting kunnen zijn, bij een inflatiegekoppelde regeling de ontwikkeling van het prijspeil. Zodra verwachtingen een rol gaan spelen treedt er onzekerheid op. Bij inflatiegekoppelde regelingen zou deze onzekerheid kunnen worden opgevangen door de reële rentetermijnstructuur te baseren op indexleningen. Deze indexleningen geven een vast basisrendement en additioneel een component die de inflatie volgt. Op deze wijze kan het indexatierisico worden geïmmuniseerd. Deze leningen zijn - in tegenstelling tot bijvoorbeeld het Verenigd Koninkrijk - in Nederland niet voorhanden. Indien we toch iets over de marktwaarde van de verplichtingen 
willen zeggen kunnen we op basis van grove aannames toch zinvolle opmerkingen plaatsen. Laten we eens uitgaan van een gemiddeld inflatiepeil van $2 \%$ en van een gemiddeld loonpeil van $3 \%$. Uitgaande van een nominaal obligatierendement van $5.5 \%$ zou - afhankelijk van de veronderstellingen - aldus een rekenrente resulteren van $5.5 \%, 3.5 \%$ c.q. $2.5 \%$. Interessant is het vervolgens om te bezien welke effecten deze wijziging van de traditionele $4 \%$ rekenrente naar deze reële rentes teweegbrengt. De onderstaande tabel geeft hiervan een indicatie?

Tabel 8 De omvang van de reserve bij verschillende veronderstellingen ten aanzien van de rekenrente

\begin{tabular}{|l|c|}
\hline rekenrente & reserve \\
\hline $5.5 \%$ & 79 \\
$4 \%$ & 100 \\
$3.5 \%$ & 109 \\
$2.5 \%$ & 130 \\
\hline
\end{tabular}

Uit de tabel kan worden afgeleid dat een verhoging van de rekenrente naar $5.5 \%$ tot een daling van de benodigde reserve met $21 \%$ leidt. Dan is er weliswaar bij de hier gehanteerde uitgangspunten geen ruimte meer voor toekomstige indexaties, maar pensioenkortingen zouden dan ook niet aan de orde zijn. Deze reserve zou als een absolute ondergrens kunnen worden gezien. Een verlaging van de rekenrente van $4 \%$ naar $3.5 \%$ leidt, bij het hier gepresenteerde fictieve pensioenfonds, tot een verhoging van de vpv met $9 \%$. Bij een rekenrente van $2.5 \%$ bedraagt de vpv $30 \%$ meer dan bij een veronderstelde $4 \%$-rekenrente. Afhankelijk van de opbouw van het pensioenfonds kunnen deze cijfers uiteraard variëren. De orde van grootte zal normaliter echter niet veel afwijken.

Samenvattend kan gesteld worden dat binnen de huidige bepaling van de reserves de indexatie er maar een beetje bij hangt en ook de uitgangspunten ten aanzien van sterfte te optimistisch zijn. Bij een prijsgekoppelde regeling zou - op basis van het uitgangspunt van marktwaardebepaling - het dan ook niet bevreemden om de benodigde reserve op te hogen met $10 \%$ à $15 \%$ en bij een loongekoppelde regeling met $30 \%$ à $35 \%$. Forse cijfers, maar wel realistische cijfers. Dit geheel plaatst de eerder geschetste overdekkingen zoals waarneembaar eind vorige eeuw in een geheel ander daglicht. Afhankelijk van de aard van de indexatie was er sprake van een beperkte overdekking c.q. zelfs een beperkte onderdekking. Waar marktwaardewaardering al niet toe kan leiden.

De eerste stap binnen het geheel van waardering van verplichtingen is daarmee gezet. De titel van de oratie is echter hoe het gesteld is met de houdbaarheid van ons pensioenstelsel. Is het geheel betaalbaar of moet de conclusie worden

\footnotetext{
${ }^{7}$ De tabel is gebaseerd op het eerder genoemde fictieve pensioenfonds.
} 
getrokken dat de kosten dermate hoog zijn, dat op termijn zulke systemen niet financierbaar zijn. Om hierop een antwoord te kunnen geven is een meer diepgaande aanpak nodig. Deze aanpak wordt aangeduid met de term Asset Liability Management (ALM), het vakgebied van mijn leerstoel. Hoe deze aanpak is vormgegeven alsmede de wijze waarop langs deze weg uitspraken kunnen worden gedaan omtrent de houdbaarheid van ons pensioenstelsel is het onderwerp in de nu volgende paragraaf.

\section{Een integrale aanpak: Asset Liability Management}

Bezien we de financiële positie van pensioenfondsen, dan moet worden geconcludeerd dat na de hoogconjunctuur in de jaren negentig van de vorige eeuw pensioenfondsen begin 2000 geconfronteerd werden met zeer sterk achterblijvende rendementen en een toenemende inflatie- en loonontwikkeling. Het is deze combinatie van lage rendementen en hoge prijs- en loonstijgingen geweest die ertoe geleid heeft dat de financiële positie van pensioenfondsen zienderogen achteruit is gegaan. Daar waar aan het begin van 2002 de discussie zich met name toespitste op het al dan niet voorwaardelijk indexeren is de financiële positie van pensioenfondsen gedurende het jaar 2002 dermate verslechterd dat een verdere bezinning omtrent de financiële opzet van het pensioenfonds benodigd is ${ }^{8}$. Teneinde het geheel van verplichtingen voortvloeiend uit de regeling en de daarvoor benodigde financiën weer met elkaar in lijn te brengen is een geïntegreerde benadering, waarbij zowel naar de verplichtingenkant als naar de vermogenszijde wordt gekeken, onontbeerlijk. Asset Liability Management (ALM) vervult daarbij een evidente rol als integratiekader waarin: 1) de doelstellingen, geformuleerd in termen van hoogte van de premievoet, premiestabiliteit, indexatieniveau en solvabiliteit, 2) de risico's, te weten loon- en prijsgroeirisico en beleggingsrisico en 3 ) het instrumentarium, namelijk het beleggingsbeleid, het vermogenswaarderingsbeleid, het financieringsbeleid en het indexatiebeleid in onderlinge samenhang worden gebracht.

Met behulp van deze geïntegreerde benadering is het mogelijk om tot een uitgekiend beleid voor een pensioenfonds te komen. Uitgekiend wil zeggen dat kosten, risico's en indexatieniveaus resulteren die door het bestuur van het pensioenfonds als acceptabel worden gekarakteriseerd. Uiteraard is het daarbij van belang dat het bestuur dit beleid helder communiceert. Zoals een jaarverslag een update is van de financiële positie van het fonds, zo zou jaarlijks een ALMupdate moeten worden uitgevoerd om het gevoerde beleid te toetsen en indien

\footnotetext{
${ }^{8} \mathrm{Om}$ een indruk te krijgen van de historische positie van de huidige beursmalaise is het interessant te vermelden dat het huidige beleggingsjaar 2002, waarbij de AEX-index in de eerste negen maanden met $40 \%$ was gedaald, de laagste stand - zowel in nominale als reële termen - van de afgelopen honderd jaar was. We hebben hier dus van doen met cen redelijk uitzonderlijke situatie.
} 
nodig aan te passen. Dit zou in de toekomst nare verrassingen moeten voorkomen.

We hebben gezien dat traditioneel bij de vaststelling van de benodigde reserve discontering plaatsvindt op basis van een rekenrente van $4 \%$. Wil de pensioenuitkering op niveau blijven, dan dient dus in ieder geval een rendement van $4 \%$ te worden behaald. Dit is evenwel nog niet voldoende. Om het pensioen waardevast (koppeling aan de prijsindex) c.q. welvaartsvast (koppeling aan de loonindex) te houden dient additioneel rendement te worden gegenereerd. Uitgaande van een gemiddeld prijsniveau van $2 \%$ impliceert dit in geval van een waardevast pensioen dat $6 \%$ rendement dient te worden gegenereerd. In geval van een welvaartsvast pensioen impliceert dit dat er $7 \%$ rendement moet worden behaald. De vraag is vervolgens welke beleggingsportefeuille geselecteerd dient te worden teneinde dat benodigde rendement te bewerkstelligen alsmede welke risico's daarmee gepaard gaan. Zoals reeds eerder is aangegeven is de enige manier om hierop een gefundeerd antwoord te geven een aanpak die gebaseerd is op ALM. Van grote importantie binnen een dergelijke ALM-aanpak zijn de veronderstellingen die gemaakt worden ten aanzien van de ontwikkeling van toekomstige beleggingsrendementen en loon- en prijsontwikkelingen. Teneinde iets zinnigs over deze toekomstige rendementen alsmede lonen en prijzen te kunnen zeggen is het van belang om het verleden nader te analyseren. Het formuleren van toekomstscenario's is het centrale onderwerp in de nu volgende paragraaf.

\section{Het formuleren van toekomstscenario's}

Het formuleren van toekomstscenario's is een hachelijke onderneming. Immers de toekomst voorspellen vindt alleen maar plaats op de kermis. Toch zullen we, als we spreken over de houdbaarheidsdatum van ons pensioenstelsel, iets over de toekomst moeten zeggen. En liefst op een verantwoorde manier. Daarvoor hebben we lange termijn scenario's nodig. Op basis van deze lange termijn scenario's kan dan het pensioenfonds als entiteit worden beschouwd en kunnen uitspraken omtrent de houdbaarheidsdatum van het pensioenstelsel worden gedaan.

De financiële grootheden die in het kader van ALM relevant zijn, zijn de prijsontwikkeling, de loonontwikkeling alsmede de rendementen op obligaties en aandelen. Veel auteurs hebben gedachten omtrent lange termijn scenario's geventileerd, waarbij de ontwikkeling van de eerder genoemde equity risk premium de centrale grootheid vormde. 
De inflatie- en loonontwikkeling

Zoals reeds eerder is aangegeven zijn de loon- en prijsontwikkeling van groot belang daar waar het het indexeren van pensioenen betreft. Indien we iets over de toekomst van pensioenregelingen willen zeggen zullen we dan ook zicht moeten hebben op deze twee grootheden. Allereerst zullen we de prijsinflatie nader bezien. De eerder genoemde studie van Dimson (2002) geeft een fraai historisch overzicht, waarbij verschillende deelperioden worden beschouwd. Dit exposé is weergegeven in tabel 10 en 11 . Om het recente verleden met betrekking tot de inflatieontwikkeling wat beter te kunnen overzien is de onderstaande figuur toegevoegd. Deze cijfers zijn ontleend aan het CBS.

Figuur 1 De ontwikkeling van de Nederlandse inflatie: periode 1971-2001

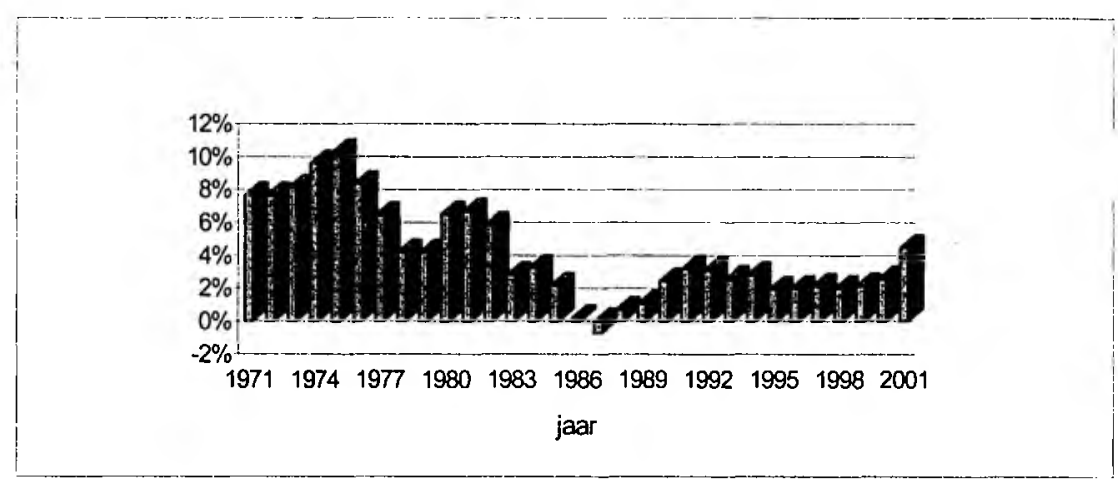

Bron: CBS prijsinflatie alle huishoudens

Bezien we de inflatieontwikkeling in Nederland zoals weergegeven in figuur 1 en tabel 10, dan valt op dat met name de jaren zeventig van de vorige eeuw gekenmerkt worden door een wel zeer hoog niveau. Gemiddeld ${ }^{9}$ bezien bedroeg over deze periode de inflatie $7.0 \%$. Slechts de periode 1940-1950 laat een hogere waarde zien (7.7\%). De periode 1980-2000 kenmerkt zich door een relatief beperkte inflatie die gelijk is aan 2.6\%. Over 1900-2000 gemeten resulteert een gemiddeld niveau van $3.0 \%$. Wat zou nu een redelijk uitgangspunt zijn ten aanzien van de toekomst? De Europese Centrale Bank (ECB) geeft aan dat haar streven erop gericht is om de inflatie laag te houden en het renteinstrument in te zetten teneinde dit gewenste niveau te bewerkstelligen. Het door de ECB nagestreefde niveau ligt op $2 \%$. Verder is het interessant te bezien hoe de inflatie zich vanaf 1983 heeft ontwikkeld. In dat jaar werden harde loonmaat-

\footnotetext{
${ }^{9}$ Het betreft hier geometrische gemiddelden. Gegeven de beperkte volatiliteit zullen geometrisch en rekenkundig gemiddelde slechts zeer beperkt verschillen.
} 
regelen afgekondigd en is er een wereld van lage inflatie ontstaan. Het gemiddelde niveau van inflatie over de periode 1983-2001, zoals dat ontleend kan worden aan de door het CBS beschikbaar gestelde gegevens, resulteert in een waarde van $2.2 \%$. Met betrekking tot het formuleren van toekomstscenario's lijkt het hanteren van een lange termijn gemiddeld niveau van rond de $2 \%$ à $2.5 \%$ dan ook realistisch. Maar aan een gemiddelde hebben we niet voldoende. We zullen ook iets over de volatiliteit van de inflatie moeten zeggen. Een maat voor de volatiliteit van een grootheid is de standaarddeviatie van die grootheid. Over de periode 1983-2001 is deze voor de inflatie gelijk aan 1.2\%. Dit lijkt aan de lage kant. Een waarde van $1.5 \%$ à $2.0 \%$ oogt meer realistisch.

Met betrekking tot de loonontwikkeling dienen eveneens uitgangspunten te worden geformuleerd. Om zicht te krijgen hoe hier de Nederlandse verhoudingen liggen is figuur 2 toegevoegd. In deze figuur wordt een overzicht gegeven van de ontwikkeling van de regelingslonen in Nederland, zoals die door het CBS worden gepubliceerd. Uit deze gegevens blijkt dat er in 1946 een tot nu toe absoluut maximum met betrekking tot loonstijging waarneembaar was, namelijk $23.1 \%$. Vervolgens zijn er in 1951,1954, 1957 alsmede in 1964 en 1965 en in de periode 1971 tot en met 1975 loonstijgingen van meer dan $10 \%$ waar te nemen. Daar waar in 1982 nog een loonstijging van $6.2 \%$ waarneembaar is, breekt in 1983 een geheel nieuwe wereld aan die gekenmerkt wordt door loonmatiging. Het duurt tot 2001 aleer er een loonstijging van meer dan $4 \%$ waarneembaar is.

Figuur 2 De Nederlandse loonontwikkeling: periode 1946-2001

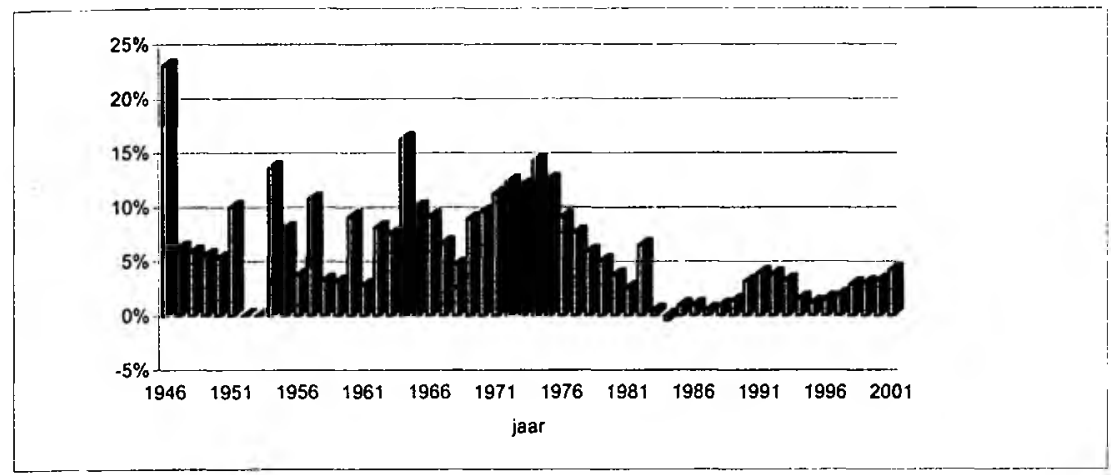

Bron: CBS regelingslonen alle huishoudens

Uit figuur 3 kan worden afgeleid dat de loonindex en de prijsindex zich tamelijk in elkaars verlengde ontwikkelen en dat de loonindex steeds boven de prijsindex ligt. Op zich is een dergelijk verschil niet vreemd. Binnen loonrondes wil men 
toch graag een prijscompensatie zien en liefst iets meer. Dat "iets meer" bedraagt, als we de periode 1971-2001 beschouwen, 0.5\%. Een gemiddeld toekomstig loonniveau van $2.5 \%$ à $3.0 \%$ is dan ook zeker verdedigbaar. Zoals verwacht mag worden is de correlatie tussen lonen en prijzen groot, hetgeen blijkt uit een waarde van $90 \%$.

Figuur 3 De Nederlandse gecumuleerde prijs- en loonontwikkeling: periode 197I-2001 $(1971=100)$

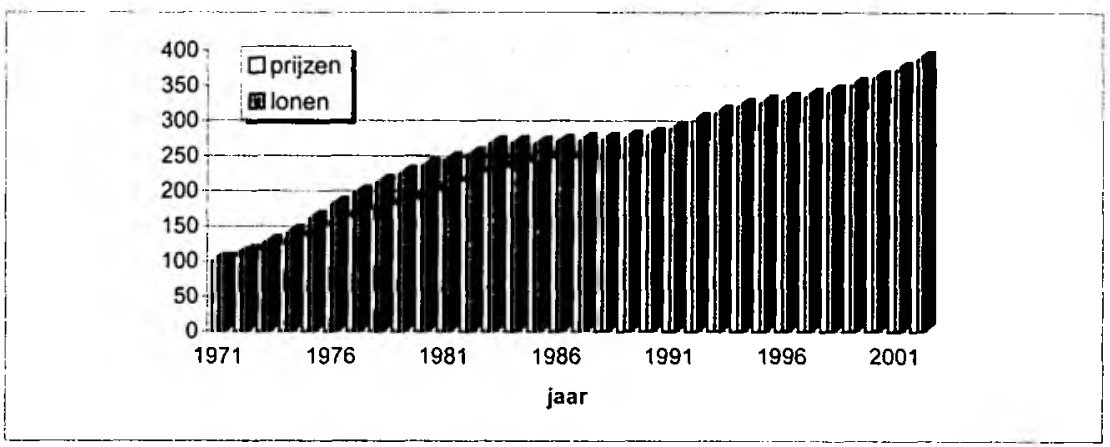

Bron: CBS prijsinflatie alle huishoudens, CBS regelingslonen alle huishoudens

Verder valt uit de CBS-cijfers af te leiden dat de volatiliteit van de lonen iets hoger ligt (ongeveer $0.5 \%$ ). Als lange termijn waarde zou een standaarddeviatie van $2.0 \%$ à $2.5 \%$ genomen kunnen worden.

\section{Obligatierendementen}

$\mathrm{Nu}$ we iets over prijzen en lonen gezegd hebben, maken we de overstap naar de beleggingswereld en proberen we soortgelijke waarden af te leiden als hiervoor beschreven voor obligaties en aandelen. We beginnen met obligaties en maken daartoe eerst een uitstapje naar de ontwikkeling van de Nederlandse lange rente. De ontwikkeling van de lange rente is in hoge mate maatgevend voor de waardeontwikkeling van de obligatieportefeuille. Bezien we het verloop van de lange rente, zoals weergegeven in figuur 4, dan kan geconcludeerd worden dat we forse rentevoeten aantreffen in de periode 1978-1981, met als hoogtepunt 1981 met een lange rente van $11.5 \%$. Vervolgens zien we een forse neergang waarbij tussentijds - in 1990 - nog eenmaal een uitschieter van $9.2 \%$ is waar te nemen. Vanaf $1996 \mathrm{komt}$ de lange rente niet meer boven de $6.0 \%$ uit, met als voorlopig historisch dieptepunt 2002, met een overeenkomstige waarde van $4.4 \%$. Gemiddeld bezien was de lange rente over de periode 1978-2002 gelijk aan $7.0 \%$, waarbij de standaarddeviatie gelijk was aan $1.9 \%$. Over de periode 
1983-2002 waren de corresponderende cijfers voor het gemiddelde $6.4 \%$ en voor de standaarddeviatie $1.4 \%$.

Figuur 4 De Nederlandse lange rente: periode 1978-2002

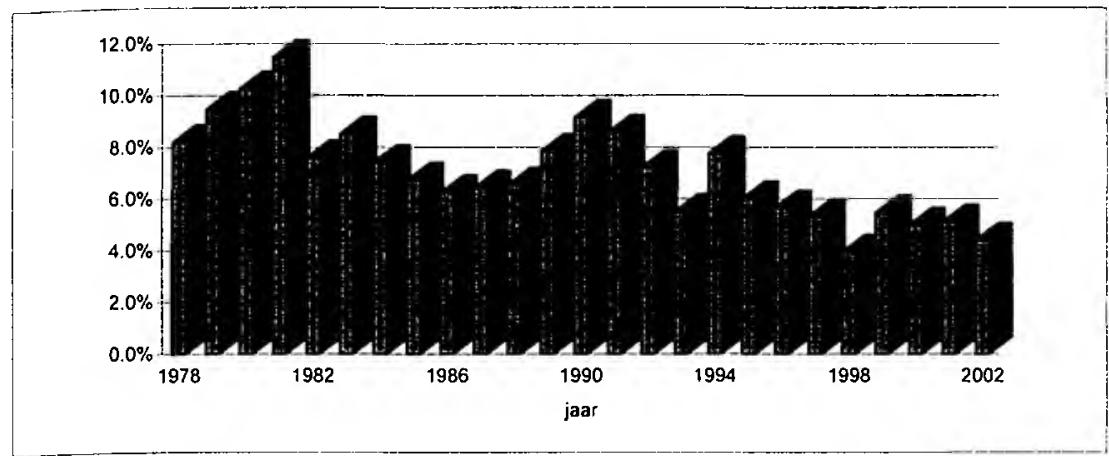

Bron: MSCI: het cijfer 2002 is gebaseerd op de stand van 9 oktober 2002

De geschetste ontwikkeling heeft een directe weerslag op de Nederlandse obligatiemarkt. Deze obligatiemarkt wordt beschreven aan de hand van figuur 5 .

Figuur 5 De Nederlandse obligatiemarkt: periode 1980-2002

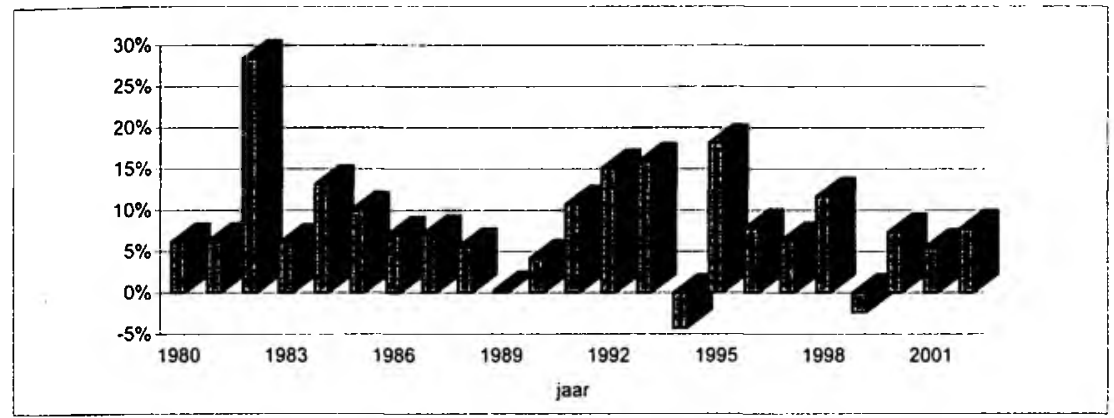

Bron: MSCI: het cijfer 2002 is gebaseerd op de stand van 9 oktober 2002

Daar waar de lange rente in 1982 fors daalde zien we dienovereenkomstig een zeer hoog obligatierendement in datzelfde jaar. Figuur 5 heeft dan ook veel weg van het spiegelbeeld van figuur 4. Worden op basis van de aan figuur 5 ten grondslag liggende gegevens gemiddelden en standaarddeviaties berekend, dan geldt dat voor de Nederlandse obligatiemarkt over de periode 1980-2002 een gemiddeld nominaal (geometrisch) rendement werd behaald van $8.2 \%$. Het overeenkomstige rekenkundige gemiddelde was gelijk aan $8.5 \%$. De bijbeho- 
rende standaarddeviatie bedroeg $6.9 \%$. Bezien we de overeenkomstige cijfers over de periode 1983-2002 dan resulteert een gemiddeld geometrisch nominaal rendement gelijk aan $7.5 \%$ en een rekenkundige gemiddelde van $7.7 \%$. De hierbij behorende standaarddeviatie bedraagt $5.7 \%$.

Beschouwen we de reële ontwikkeling van de obligatierendementen dan resulteert een geometrisch gemiddelde over de periode 1983-2001 van 5.3\%, daar waar het overeenkomstige rendement in nominale termen $7.5 \%$ bedroeg. Een verschil aldus van $2.2 \%$. Om een beter zicht te krijgen op de ontwikkeling van de reële obligatierendementen vallen we terug op de studie van Dimson (2002) en de daarin gepresenteerde cijfers. Deze cijfers zijn weergegeven in tabel 10 en in tabel 11 . Uit tabel $10 \mathrm{kan}$ worden afgeleid dat de waargenomen reële rendementen op Nederlandse obligaties van de afgelopen twintig jaar, gerelateerd aan een horizon van 101 jaar, als zeer fors mogen worden aangeduid. Het gemiddelde rendement over deze lange horizon is slechts $1.1 \%$, hetgeen in schril contrast staat met de eerder genoemde $5.3 \%$. Ook voor de wereldmarkt is een dergelijk fenomeen ten aanzien van het gemiddelde reële obligatierendement waarneembaar. Over de afgelopen twintig jaar ligt dit gemiddelde zelfs boven de $6 \%$, daar waar over de gehele periode van 101 jaar dit gemiddelde $1.2 \%$ bedraagt.

De vraag is dan ook wat een redelijke schatting van het lange termijn rendement op een obligatieportefeuille zou kunnen zijn. Bezien we de nominale lange rente in het Euro-gebied dan beweegt deze rond een niveau van $5 \%$ à $5.5 \%$. Een redelijke schatting voor de ontwikkeling van de obligatierendementen op de langere termijn zou dan ook in deze orde van grootte kunnen liggen. Ten aanzien van de standaarddeviatie van dit gemiddelde lijkt het in tabel 6 genoemde getal van $8.5 \%$ een redelijke schatting.

\section{Aandeelrendementen}

Aandelen zijn de kurk waarop de Nederlandse pensioenfondsen tot dusver gedreven hebben. Deze kurk lijkt evenwel zijn beste tijd achter de rug te hebben. De laatste drie jaren, 2000 tot en met september 2002, hebben een rendementsontwikkeling laten zien die verre van florissant was. Het gevolg was, zoals we in het voorgaande gezien hebben, dat pensioenfondsen hun reserves als sneeuw voor de zon zagen verdwijnen. De vraag is dan ook: wat mogen we van de toekomst verwachten? Om die vraag te kunnen beantwoorden bekijken we allereerst de Nederlandse aandelenmarkt. Hiertoe is de onderstaande figuur toegevoegd. 
Figuur 6 De Nederlandse aandelenmarkt: periode 1970-2002

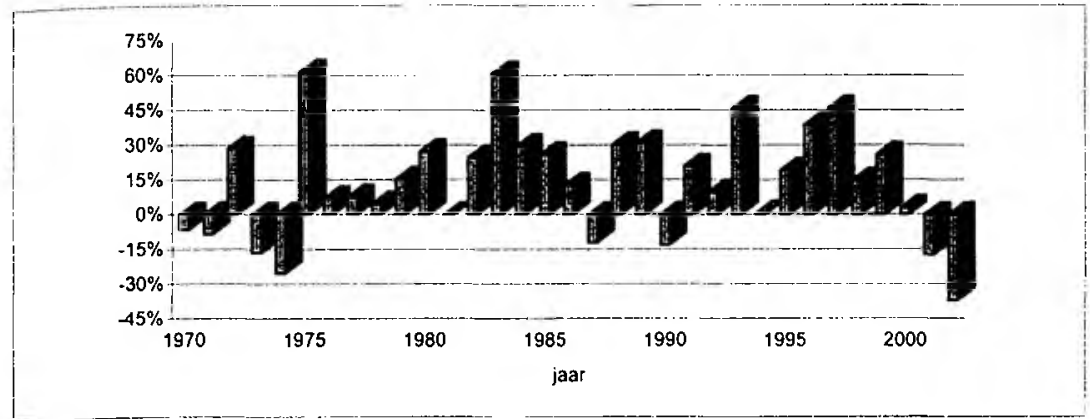

Bron: MSCI: het cijfer 2002 is gebaseerd op de stand van 9 oktober 2002

Bezien we de ontwikkeling van deze aandeelrendementen voor de Nederlandse markt dan zijn er enorme uitschieters - met name aan de bovenzijde - waar te nemen. In 1975 en in 1983 werd er op de Nederlandse aandelenmarkt een rendement behaald van meer dan $60 \%$. Rendementen van boven de $20 \%$ vormden eerder regelmaat dan uitzondering. Van alle waarnemingen lag meer dan $40 \%$ boven deze grens van $20 \%$. Ongeveer $25 \%$ van alle waarnemingen betrof rendementen die lagen beneden de $0 \%$. Gesteld mag dan ook worden dat de bandbreedte waarbinnen aandelen zich bewegen zeer fors is. Dit uit zich dan ook in een hoge standaardafwijking. Over de hier geëvalueerde periode bedroeg deze bijna $25 \%$. Het geometrische gemiddelde rendement over deze periode was gelijk aan $11.2 \%$. Het overeenkomstige rekenkundige gemiddelde had een waarde van $13.7 \%$. Om ook iets te kunnen zeggen over de reële rendementen moeten we wat verder de historie induiken en maken we gebruik van de tabellen 10 en 11 . Bezien we tabel 10 dan valt op dat uit de daarin aangegeven vijfenvijftig deelperioden ${ }^{10}$ er vijf deelperioden te onderkennen zijn waarop aandelen een reëel rendement laten zien van $10 \%$ of meer. Het betreft hier de perioden 1) $1950-1959$ (13.6\%), 2) $1970-2000(10.0 \%)$, 3) 1980-1989 (16.8\%), 4) 1980$2000(16.1 \%$ ) en 5) 1990-2000 (15.5\%). Bezien vanuit het jaar 2000 zijn de reële aandeelrendementen vanaf $197010 \%$ of hoger. Dat mag - gegeven de historie - als substantieel worden aangemerkt. Verder valt op dat er slechts éen periode is met een negatief reëel rendement op aandelen en dat is de periode $1970-1979(-1.8 \%)$. De oorzaak van deze negatieve waarde is de forse inflatie die in deze periode is waar te nemen. Het nominale rendement op aandelen lag in deze periode op $5.7 \%$, het gemiddelde inflatieniveau bedroeg over dit tijdsinterval $7.0 \%$.

Bezien we tabel 11, waarin de ontwikkeling van de wereldmarkt wordt beschreven, dan is een soortgelijk beeld waar te nemen. Ook hier geldt dat in de

\footnotetext{
${ }^{10}$ We laten het jaar 2000 buiten beschouwing daar het hier om cen tijdsinterval van slechts één jaar gaal.
} 
periode 1950-1959 zeer forse reële aandeelrendementen worden gegenereerd (17.1\%). Over de periode 1950-1969 liggen deze reële rendementen nog steeds boven de 10\% (11.2\%). Ook voor de periode 1980-1989 geldt een hoog reëel rendement $(13.5 \%)$. Het enige negatieve reële rendement is waar te nemen over de periode 1910-1919 (-3.7\%), hetgeen echter gevolgd wordt door een decennium van zeer forse reële rendementen $(13.0 \%)$.

Willen we iets zeggen over de te verwachten aandeelrendementen, dan is de ontwikkeling van de equity risk premium de sleutelgrootheid. Deze grootheid knoopt als het ware de rendementen van obligaties en aandelen aan elkaar. Op basis van voornoemde tabellen kan worden afgeleid dat gedurende de periode 1940-1970 de Nederlandse aandelenmarkt een zeer hoge risicopremie in zich droeg van rond de $10 \%$ met als uitschieter $17.2 \%$ in de jaren $1950-1959$. Een dergelijk verloop zien we terugkeren in de periode 1980-2000. Ook hier lagen de risicopremies rond de $10 \%$. Over de gehele tijdshorizon van 101 jaar is echter slechts een risicopremie waarneembaar van $4.7 \%$ op de Nederlandse markt en een nagenoeg gelijk percentage van 4.6 op de wereldmarkt. Dat is nogal een verschil. Dus blijft de vraag, wat is nu redelijk om naar de toekomst toe met betrekking tot die risicopremie te verwachten? Binnen de financieringsliteratuur is de equity risk premium een onderwerp dat thans veel aandacht krijgt. Veel papers suggereren dat de terugval in het verwachte aandelenrendement deels permanent is als gevolg van (a) de toename van de participatiegraad door individuen en instituten en (b) de lagere kosten die verbonden zijn aan het diversificeren van aandeelportefeuilles (Diamond (1999), Heaton and Lucas (1999) and Siegel (1999)). Er is echter ook bewijs dat het verwachte rendement op aandelen langzaam mean reverting is, dat wil zeggen langzaam naar z'n gemiddelde beweegt (zie Fama and French (1989) en Cochrane (1994)). Er zijn eigenlijk twee denkrichtingen te onderscheiden met betrekking tot het verklaren van de verandering in de verwachte beleggingsopbrengsten. De ene richting verklaart de verandering uit rationele wijzigingen van de reactie op macroeconomische factoren (zie Fama and French (1989), Blanchard (1993) en Cochrane (1994)). Andere auteurs, bijvoorbeeld Shiller (1989), oordelen dat irrationele bewegingen in beleggingssentiment de belangrijkste drijvende kracht zijn. Wat de redenen voor de wijziging ook mogen zijn en de vraag of dit tijdelijk of deels permanent is, de boodschap is volgens Fama en French (2002) dat we een periode tegemoet gaan van lagere verwachte rendementen. Op basis van de in deze studie gehanteerde aanpak en de verdere uitwerking hiervan binnen Dimson (2002) kan worden afgeleid dat de gemiddelde geometrische risicopremie $2.8 \%$ bedraagt en de overeenkomstige rekenkundige gemiddelde risicopremie rond de $3.8 \%$ ligt. De redenering achter deze risicopremies is de volgende. Wordt de afgelopen eeuw in ogenschouw genomen dan blijkt dat het reële rendement op aandelen $5.8 \%$ bedroeg en op obligaties $1.2 \%$, waardoor gemiddeld bezien een risico-opslag oftewel een risicopremie, van $4.6 \%$ resulteer- 
de. Op basis van de voornoemde studies moet deze $4.6 \%$ gecorrigeerd worden voor twee facetten. Het eerste facet betreft de onverwacht snelle stijging van de winsten van bedrijven in de afgelopen honderd jaar. Keer op keer werd de beurs verrast door de technologische vooruitgang en de effecten op de productiviteit die leidden tot onverwacht hoge cashflows. Dergelijke meevallers zijn volgens de onderzoekers goed voor $0.6 \%$-punt. Het tweede facet betreft het opdrijvend effect op het rendement van aandelen als gevolg van de toegenomen vraag naar aandelen. Volgens de auteurs moet additioneel $1.2 \%$-punt van de koerswinst per jaar die in de $20^{\text {stc }}$ eeuw werd geboekt op de risicopremie in mindering gebracht worden doordat aandelen plotseling populair werden onder beleggers. Vooral de afgelopen decennia stortte het publiek zich massaal op de beurs. Tegelijkertijd ontstonden meer mogelijkheden om portefeuilles te spreiden en kregen beleggers het gevoel dat de wereld stabieler werd. Gecorrigeerd voor geluk en eenmalige factoren moet de belegger die anno 2002 instapt, op historische basis rekening houden met een risicopremie die 1.8\%-punt lager ligt dan in het verleden. Volgens de auteurs resulteert aldus een (geometrische) risicopremie van $2.8 \%$ punt. De overeenkomstige rekenkundig bepaalde risicopremie zou dan op basis van de eerder gepresenteerde standaarddeviatie van de risicopremie van $14.5 \%$ gelijk zijn aan $3.8 \%$.

Indien we alle vorenstaande overwegingen samenvatten dan krijgen we een aardige indruk van de verwachtingen ten aanzien van de toekomst. Dit resulteert in het onderstaande scenario.

Tabel 9 Een mogelijk toekomstscenario

\begin{tabular}{|l|l|c|c|c|}
\hline \multirow{2}{*}{$\begin{array}{l}\text { nominale } \\
\text { rendementen }\end{array}$} & grootheid & $\begin{array}{c}\text { geometrisch } \\
\text { gemiddelde }\end{array}$ & $\begin{array}{c}\text { rekenkundig } \\
\text { gemiddelde }\end{array}$ & $\begin{array}{c}\text { standaard- } \\
\text { deviatie }\end{array}$ \\
\cline { 2 - 5 } & obligaties & 5.0 & 9.2 & 16.5 \\
\cline { 2 - 5 } & inflatie & 2.0 & 2.0 & 8.5 \\
\cline { 2 - 5 } & lonen & 2.5 & 2.5 & 2.0 \\
\hline \multirow{2}{*}{$\begin{array}{l}\text { reële } \\
\text { rendementen }\end{array}$} & aandelen & 5.8 & 7.2 & 17.0 \\
\cline { 2 - 5 } & obligaties & 3.0 & 3.4 & 10.3 \\
\hline risicopremie & aandelen & 2.8 & 3.8 & 14.5 \\
\hline
\end{tabular}


Tabel 10 Overzicht van de reële ontwikkeling van rendementen en van de inflatie voor de Nederlandse markt over de periode 1900-2000

\begin{tabular}{|c|c|c|c|c|c|c|c|c|c|c|c|c|}
\hline & van & 1900 & 1910 & 1920 & 1930 & 1940 & 1950 & 1960 & 1970 & 1980 & 1990 & 2000 \\
\hline & tol & & & & & & & & & & & \\
\hline reëel & 1909 & 4.8 & & & & & & & & & & \\
\hline rendement & 1919 & 3.0 & 1.3 & & & & & & & & & \\
\hline op & 1929 & 2.5 & 1.4 & 1.5 & & & & & & & & \\
\hline \multirow[t]{7}{*}{ aandelen } & 1939 & 2.6 & 1.8 & 2.1 & 2.7 & & & & & & & \\
\hline & 1949 & 2.5 & 1.9 & 2.1 & 2.4 & 2.2 & & & & & & \\
\hline & 1959 & 4.3 & 4.2 & 4.9 & 6.0 & 7.8 & 13.6 & & & & & \\
\hline & 1969 & 4.0 & 3.9 & 4.4 & 5.2 & 6.0 & 8.0 & 2.5 & & & & \\
\hline & 1979 & 3.3 & 3.1 & 3.4 & 3.7 & 4.0 & 4.6 & 0.4 & -1.8 & & & \\
\hline & 1989 & 4.7 & 4.7 & 5.2 & 5.8 & 6.4 & 7.5 & 5.6 & 7.1 & 16.8 & & \\
\hline & 2000 & 5.8 & 5.9 & 6.5 & 7.2 & 8.0 & 9.2 & 8.1 & 10.0 & 16.1 & 15.5 & -4.9 \\
\hline reëel & 1909 & 0.3 & & & & & & & & & & \\
\hline rendement & 1919 & -2.9 & -6 & & & & & & & & & \\
\hline op & 1929 & 0.9 & 1.1 & 8.8 & & & & & & & & \\
\hline \multirow[t]{7}{*}{ obligatics } & 1939 & 1.9 & 2.5 & 7.0 & 5.2 & & & & & & & \\
\hline & 1949 & 1.2 & 1.5 & 4.1 & 1.8 & -1.5 & & & & & & \\
\hline & 1959 & 0.5 & 0.6 & 2.3 & 0.2 & -2.3 & -3.0 & & & & & \\
\hline & 1969 & -0.1 & -0.2 & 1.1 & -0.8 & -2.7 & -3.3 & -3.7 & & & & \\
\hline & 1979 & -0.1 & -0.1 & 0.9 & -0.7 & -2.1 & -2.3 & -1.9 & -0.1 & & & \\
\hline & 1989 & 0.6 & 0.6 & 1.6 & 0.4 & -0.5 & -0.3 & 0.7 & 2.9 & 5.9 & & \\
\hline & 2000 & 1.1 & 1.2 & 2.1 & 1.2 & 0.5 & 1.0 & 1.9 & 3.8 & 5.7 & 5.6 & 4.4 \\
\hline \multirow[t]{10}{*}{ inflatic } & 1909 & 1.9 & & & & & & & & & & \\
\hline & 1919 & 3.9 & 5.9 & & & & & & & & & \\
\hline & 1929 & 1.7 & 1.6 & -2.5 & & & & & & & & \\
\hline & 1939 & 0.7 & 0.3 & -2.4 & -2.3 & & & & & & & \\
\hline & 1949 & 2.0 & 2.1 & 0.9 & 2.6 & 7.7 & & & & & & \\
\hline & 1959 & 2.3 & 2.4 & 1.5 & 2.9 & 5.5 & 3.5 & & & & & \\
\hline & 1969 & 2.6 & 2.7 & 2.1 & 3.2 & 5.1 & 3.9 & 4.4 & & & & \\
\hline & 1979 & 3.1 & 3.3 & 2.9 & 4.0 & 5.6 & 4.9 & 5.7 & 7.0 & & & \\
\hline & 1989 & 3.1 & 3.2 & 2.9 & 3.8 & 5.0 & 4.4 & 4.7 & 4.9 & 2.8 & & \\
\hline & 2000 & 3.0 & 3.1 & 2.8 & 3.6 & 4.6 & 4.0 & 4.1 & 4.0 & 2.6 & 2.5 & 2.9 \\
\hline equity & 1909 & 4.5 & & & & & & & & & & \\
\hline & 1919 & 6.1 & 7.8 & & & & & & & & & \\
\hline \multirow[t]{8}{*}{ premium } & 1929 & 1.7 & 0.3 & -6.7 & & & & & & & & \\
\hline & 1939 & 0.6 & -0.6 & -4.6 & -2.4 & & & & & & & \\
\hline & 1949 & 1.2 & 0.4 & -1.9 & 0.6 & 3.8 & & & & & & \\
\hline & 1959 & 3.7 & 3.6 & 2.6 & 5.9 & 10.3 & 17.2 & & & & & \\
\hline & 1969 & 4.1 & 4.1 & 3.3 & 6.0 & 9.0 & 11.7 & 6.4 & & & & \\
\hline & 1979 & 3.4 & 3.2 & 2.5 & 4.4 & 6.2 & 7.0 & 2.3 & -1.7 & & & \\
\hline & 1989 & 4.1 & 4.1 & 3.6 & 5.4 & 7.0 & 7.8 & 4.9 & 4.1 & 10.2 & & \\
\hline & 2000 & 4.7 & 4.7 & 4.3 & 6.0 & 7.4 & 8.2 & 6.1 & 5.9 & 9.8 & 9.4 & -9.0 \\
\hline
\end{tabular}

Bron: Dimson, E., P. March and M. Staunton (2002), tabel 27-2 en 27-3 
Tabel 11 Overzicht van de reële ontwikkeling van rendementen en van de inflatie voor de wereldmarkt over de periode 1900-2000

\begin{tabular}{|c|c|c|c|c|c|c|c|c|c|c|c|c|}
\hline & van & 1900 & 1910 & 1920 & 1930 & 1940 & 1950 & 1960 & 1970 & 1980 & 1990 & 2000 \\
\hline & tot & & & & & & & & & & & \\
\hline reëel & 1909 & 5.4 & & & & & & & & & & \\
\hline rendement & 1919 & 0.8 & -3.7 & & & & & & & & & \\
\hline op & 1929 & 4.7 & 4.3 & 13.0 & & & & & & & & \\
\hline \multirow[t]{7}{*}{ aandelen } & 1939 & 3.9 & 3.4 & 7.2 & 1.7 & & & & & & & \\
\hline & 1949 & 3.3 & 2.8 & 5.1 & 1.4 & 1.0 & & & & & & \\
\hline & 1959 & 5.5 & 5.5 & 8.0 & 6.4 & 8.8 & 17.1 & & & & & \\
\hline & 1969 & 5.5 & 5.5 & 7.5 & 6.1 & 7.7 & 11.2 & 5.5 & & & & \\
\hline & 1979 & 4.9 & 4.9 & 6.4 & 5.1 & 5.9 & 7.6 & 3.1 & 0.9 & & & \\
\hline & $1989^{\circ}$ & 5.8 & 5.9 & 7.3 & 6.4 & 7.4 & 9.1 & 6.5 & 7.0 & 13.5 & & \\
\hline & 2000 & 5.8 & 5.8 & 7.1 & 6.3 & 7.0 & 8.1 & 6.2 & 6.4 & 9.2 & 5.4 & -16.0 \\
\hline reëel & 1909 & 0.3 & & & & & & & & & & \\
\hline rendement & 1919 & -3.9 & -7.9 & & & & & & & & & \\
\hline op & 1929 & -0.9 & -1.4 & 5.5 & & & & & & & & \\
\hline \multirow[t]{7}{*}{ obligaties } & 1939 & 0.6 & 0.8 & 5.4 & 5.3 & & & & & & & \\
\hline & 1949 & -0.5 & -0.7 & 1.9 & 0.1 & -4.8 & & & & & & \\
\hline & 1959 & -0.5 & -0.6 & 1.3 & -0.1 & -2.7 & -0.4 & & & & & \\
\hline & 1969 & -0.3 & -0.4 & 1.2 & 0.1 & -1.6 & 0.1 & 0.6 & & & & \\
\hline & 1979 & -0.1 & -0.1 & 1.2 & 0.4 & -0.8 & 0.6 & 1.1 & 1.6 & & & \\
\hline & 1989 & 0.6 & 0.7 & 2.0 & 1.4 & 0.6 & 2.0 & 2.9 & 4.0 & 6.6 & & \\
\hline & 2000 & 1.2 & 1.3 & 2.5 & 2.1 & 1.5 & 2.8 & 3.7 & 4.7 & 6.2 & 5.8 & 3.6 \\
\hline inflatie & 1909 & 2.4 & & & & & & & & & & \\
\hline \multirow[t]{9}{*}{ (VS) } & 1919 & 4.8 & 7.3 & & & & & & & & & \\
\hline & 1929 & 2.9 & 3.1 & -1.0 & & & & & & & & \\
\hline & 1939 & 1.6 & 1.4 & -1.5 & -2.0 & & & & & & & \\
\hline & 1949 & 2.4 & 2.4 & 0.7 & 1.6 & 5.4 & & & & & & \\
\hline & 1959 & 2.3 & 2.3 & 1.1 & 1.8 & 3.8 & 2.2 & & & & & \\
\hline & 1969 & 2.4 & 2.4 & 1.4 & 2.0 & 3.4 & 2.4 & 2.5 & & & & \\
\hline & 1979 & 3.0 & 3.1 & 2.4 & 3.0 & 4.4 & 4.0 & 4.9 & 7.4 & & & \\
\hline & 1989 & 3.2 & 3.3 & 2.7 & 3.4 & 4.5 & 4.3 & 5.0 & 6.2 & 5.1 & & \\
\hline & 2000 & 3.2 & 3.3 & 2.8 & 3.3 & 4.2 & 4.0 & 4.4 & 5.1 & 4.0 & 3.0 & 3.4 \\
\hline equity & 1909 & 5.2 & & & & & & & & & & \\
\hline risk & 1919 & 4.9 & 4.6 & & & & & & & & & \\
\hline \multirow[t]{8}{*}{ premium } & 1929 & 5.6 & 5.8 & 7.1 & & & & & & & & \\
\hline & 1939 & 3.3 & 2.7 & 1.7 & -3.4 & & & & & & & \\
\hline & 1949 & 3.8 & 3.5 & 3.2 & 1.2 & 6.1 & & & & & & \\
\hline & 1959 & 6.0 & 6.2 & 6.6 & 6.4 & 11.8 & 17.7 & & & & & \\
\hline & 1969 & 5.9 & 6.0 & 6.3 & 6.0 & 9.4 & 11.1 & 4.9 & & & & \\
\hline & 1979 & 5.0 & 5.0 & 5.1 & 4.7 & 6.8 & 7.0 & 2.0 & -0.7 & & & \\
\hline & 1989 & 5.2 & 5.2 & 5.3 & 5.0 & 6.7 & 6.9 & 3.5 & 2.8 & 6.5 & & \\
\hline & 2000 & 4.6 & 4.5 & 4.5 & 4.1 & 5.4 & 5.3 & 2.4 & 1.7 & 2.8 & -0.4 & -18.9 \\
\hline
\end{tabular}




\section{Het huidige tijdsgewricht en de houdbaarheidsdatum van ons pensioenstelsel}

\section{Het wettelijk kader}

Pensioenfondsen worden thans geconfronteerd met een economische omgeving die verre van florissant is. Daar waar ultimo 1999 de houdbaarheid in zijn geheel niet ter discussie stond, ontstaat als gevolg van de zware koersval van aandelen sindsdien een geheel andere situatie. Het waren met name deze aandeelrendementen die er in het verleden toe hebben bijgedragen dat pensioenfondsen tot hoge dekkingsgraden kwamen en dientengevolge (grote) delen van de benodigde inkomsten konden financieren uit deze forse beleggingsrendementen. Die fase hebben we nu alweer bijna drie jaar achter ons liggen. Het gevolg is dat er veel pensioenfondsen geconfronteerd worden met een dekkingsgraad van rond de $100 \%$. Hierdoor is er dus nagenoeg niet meer aan premieverhogingen te ontkomen. Maar is een premieverhoging voldoende en/of dient de aandeelportefeuille te worden afgebouwd? Hoe ziet de premieontwikkeling er naar de toekomst toe uit? Zijn er wellicht nog extra stortingen benodigd? Dient er over gegaan te worden tot voorwaardelijke indexatie? Vragen die thans heel actueel zijn en van groot belang in het kader van de continuïteit van ons pensioenstelsel. Niet onbelangrijk in dit geheel is ook de brief van de toezichthouder, de PVK (2002a), die op 30 september jl. op de mat van de pensioenfondsbestuurders belandde. In dit schrijven worden uitgangspunten voor de financiële opzet en positie van pensioenfondsen geformuleerd. Het volgende wordt hierin gesteld: "Het betreft hier richtlijnen met betrekking tot het te voeren korte termijn beleid als richtlijnen om op wat langere termijn de positie van fondsen zodanig te herstellen dat in de toekomst ook een situatie als de huidige, met aanhoudend slechte rendementen, kan worden opgevangen. De aanpak kent twee lijnen. De eerste is het wegnemen van de situaties van onderdekking bij fondsen waarbij onderdekking is opgetreden. De tweede is het in de komende jaren weer op peil brengen van de financiële ruimte die nodig is om het door de fondsen voorgestane beleid en beheer uit te voeren. Deze aanpak moet eraan bijdragen het Nederlandse pensioenstelsel ook op de langere termijn, die nu eenmaal kenmerkend is voor pensioenen, zeker en betaalbaar te houden".

Een zeker en betaalbaar pensioen ook op de langere termijn, dat is de kernboodschap van de notitie van de PVK. Maar zijn boodschap en feitelijke invulling van richtlijnen wel met elkaar in overeenstemming? Of wordt als gevolg van het in de richtlijnen aangegeven actieplan een dermate zwaar beroep gedaan op de financiën van ondernemingen en/of bedrijfstakken dat zij niet bereid zijn de benodigde middelen te verstrekken. Dit kan leiden tot een versobering van de regeling, iets waar thans niemand op zit te wachten. Verder leidt een hoge 
bijdrage van de onderneming c.q. de bedrijfstak aan het pensioenfonds tot een afkalving van de winst. Dit werkt een verdere daling van de waarde van de aandelen van deze partijen in de hand. Ook dit is niet wenselijk.

\section{Betaalbaarheid: het spanningsveld}

Als we het onderwerp betaalbaarheid bezien dan gaat het om de jaarlijkse premiestortingen. Bezien vanuit de optiek van de gemiddelde lange termijn premiehoogte is het beleggen in aandelen aantrekkelijk. Beleggen in aandelen kan echter leiden tot forse jaarlijkse rendementsfluctuaties. Voor wat betreft fluctuatieaspecten van de premievoet is het beleggen in vastrentende waarden aantrekkelijk. Besturen van pensioenfondsen prefereren vanzelfsprekend een lage premie boven een hoge premie, maar beschouwen te grote fluctuaties van die premievoet veelal als zeer ongewenst. Verder speelt de solvabiliteitspositie een prominente rol, het zeker stellen van pensioenen op de lange termijn is daarbij het adagium. Uiteraard is het doel van adequaat bestuur dat de solvabiliteit niet in het gedrang komt. Helaas staat het drietal premiehoogte, premiestabiliteit en solvabiliteit op gespannen voet. Met behulp van het onderstaande figuurtje zal dit nader worden geduid.

Figuur 7 Het spanningsveld bij de bepaling van de premievoet

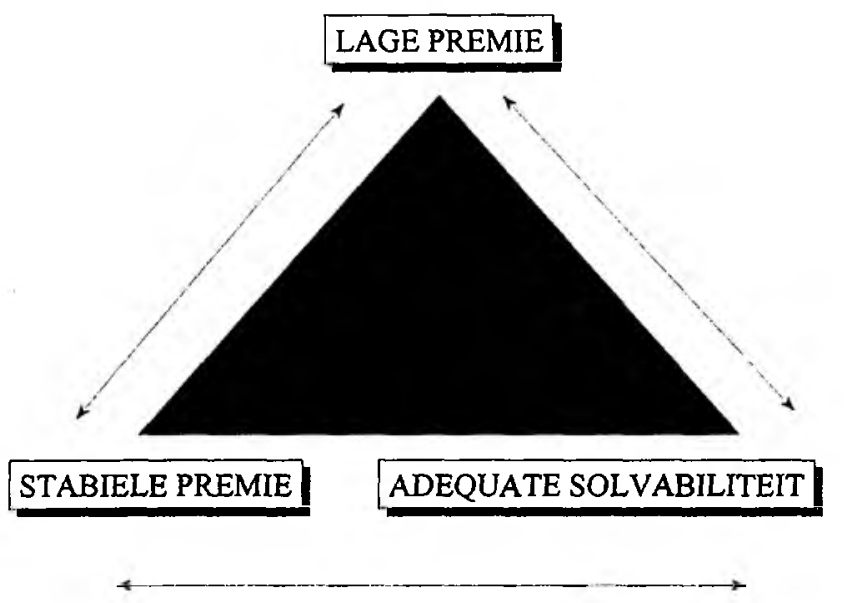

Het spanningsveld kan als volgt worden getypeerd: "zodra aan twee van de randvoorwaarden (aangegeven door de tekst in de hoekpunten) invulling is gegeven zal de derde randvoorwaarde onder spanning staan". Dit kan als volgt worden toegelicht. Wordt voor de criteria stabiele premie en lage premie 
geopteerd, dan kan dit bewerkstelligd worden door de premievoet gelijk te stellen aan $0 \%$. Adequate solvabiliteit zal normaliter hierdoor niet worden bewerkstelligd. Wordt voor de criteria stabiele premie en adequate solvabiliteit gekozen, dan kan dit worden bewerkstelligd door de premievoet gelijk te stellen aan $50 \%$. Aan het criterium van lage premie wordt dan evenwel niet voldaan. Tot slot, indien adequate solvabiliteit en lage premie als uitgangspunt dienen, dan zal de premievoet jaarlijks fors kunnen muteren, waarbij niet langer aan het criterium van stabiele premie tegemoet wordt gekomen. Vastgesteld moet dan ook worden dat de vormgeving van het beleid altijd concessies met zich meebrengt. Het op een uitgebalanceerde wijze omgaan met deze concessies dient dan ook het uitgangspunt van de vormgeving van het beleid te zijn. Het instrumentarium dat een bestuur daarvoor ter beschikking heeft om evenwicht te brengen in de bovenstaande driehoek is al eerder aan de orde geweest en bestaat uit het beleggingsbeleid, het vermogenswaarderingsbeleid (bufferbepaling), het financieringsbeleid en het indexatiebeleid. Maar dan toch nog even terug naar de opmerking dat de solvabiliteit niet in het gedrang mag komen. Wat wordt concreet bedoeld met "niet in het gedrang komen". Betekent dit dat onder alle omstandigheden er een dekkingsgraad dient te zijn van tenminste $100 \%$ ? Dat zou prachtig zijn. Er zijn echter situaties denkbaar die dermate extreem zijn, dat het de vraag is of we het beleid nu al zo willen inrichten dat ook onder zelfs die omstandigheden het fonds overeind blijft. Want aan dat overeind blijven hangt veelal een heel fors prijskaartje in de zin van hoge premievoeten. Vandaar dat ALM ontwikkeld is. Van der Meer en Smink (1998) stellen dat "ALM het systematisch structureren van financiële risico's verbonden aan de activa en passiva portefeuilles van financiële instellingen behelst teneinde een doelmatig risico/rendementsprofiel voor de instelling als entiteit te bewerkstelligen". Doelmatig wil hierbij zeggen dat de uitkomsten van de strategie passen binnen het daartoe aangedragen risicokader. Maar helaas, de PVK draagt geen risicokader aan en dat maakt dat het kompas waarop gestuurd dient te worden ontbreekt. Het los van elkaar beschouwen van beleidsinstrumenten of het aandragen van restricties ten aanzien van componenten los van overige componenten past dan ook niet. Dit is eigenlijk het grootste manco van de huidige PVK-richtlijnen. Het overall toetsingskader ontbreekt.

Tot en met 2001 werden er door pensioenfondsen strakke normen gehanteerd met betrekking tot het te lopen risico. Dit risico werd veelal uitgedrukt in de mate waarin kansen op onderdekking zich mochten voordoen. Een realistisch uitgangspunt daarbij was dat deze kansen op onderdekking, bezien over een horizon van tien jaar, niet groter mochten zijn dan $5 \%$. Vervolgens resulteerden aanbevelingen ten aanzien van de inrichting van het financieringssysteem, de wijze van vermogenswaardering en de samenstelling van de beleggingsportefeuille. In 2001 leidde dit uitgangspunt ten aanzien van de risicotolerantie tot de conclusie dat aandeelportefeuilles afgebouwd dienden te worden. Met andere 
woorden, het relatieve belang in aandelen diende te worden beperkt. Deze aandelenportefeuilles waren echter tot op dat moment de motor van de rendementsgeneratie. Het afstoten van aandelen was vanuit risico-optiek te prefereren, vanuit de optiek van toekomstige rendementsontwikkeling was dit echter onwenselijk. Het dilemma lag op tafel. En toen kwam 2002 en werd alles nog een graadje erger. Aandelenmarkten vielen geheel terug met als gevolg dat pensioenfondsen nog verder op hun vermogensbuffers inteerden, zoniet hun vermogensbuffers tot nul zagen reduceren. Een lichte paniek maakte zich van de pensioenwereld meester. Maar was het zo dramatisch dat vermogensbuffers opdroogden? Ja en nee. Ja, omdat naar de toekomst toe deze buffers weer gevuld moeten worden, hetgeen ten koste gaat van premieverlagingen. Een ander negatief aspect betreft het feit dat als gevolg van de terugval van de aandelenmarkt de ruimte om risico te nemen beperkter werd, waarbij het de vraag was in hoeverre beleggingsportefeuilles herschikt dienden te worden teneinde weer in lijn te komen met het van tevoren aangegeven risicokader. Nee, omdat de buffers daarvoor waren gereserveerd. Indien vermogensbuffers slechts gedeeltelijk zouden worden aangesproken, zou er sprake zijn van een soort van ijzeren voorraad, dood geld waar niets mee wordt gedaan. Van belang is het dus om te bezien op welke wijze het beleggingsbeleid zou moeten worden vormgegeven teneinde ook op termijn het pensioenstelsel overeind te houden. En dan komt het beleggingsbeleid om de hoek kijken.

\section{Het beleggingsbeleid}

Tal van strategieën kunnen hierbij worden bedacht, maar laten we het spectrum beperkt houden tot een tweetal systemen. Binnen het eerste systeem wordt uitgegaan van een constante mix strategie, hetgeen inhoudt dat de beleggingsportefeuille aan het einde van elk jaar wordt herschikt conform vaste gewichten. Het relatieve belang van de verschillende deelportefeuilles binnen de totale portefeuille is door toepassing van deze methodiek constant in de tijd. Binnen het tweede systeem wordt een beleggingsstrategie gehanteerd die getypeerd wordt als een buy and hold beleid. Binnen een buy and hold beleid ontwikkelen de verschillende deelportefeuilles zich los van elkaar. Daar er geen relaties liggen tussen deze portefeuilles is het relatieve belang van de verschillende deelportefeuilles over de tijd bezien niet langer constant maar varieert dit. $\mathrm{Bij}$ een constante mix strategie is het uitgangspunt dat markten mean reverting zijn, dat wil zeggen dat rendementen terugkeren naar hun gemiddelde. Als je dus een koerswinst hebt gehad dan moet om weer op dat gemiddelde uit te komen er ook weer een daling gaan optreden. Dat impliceert dus bij marktstijgingen waarden verkopen en bij marktdalingen waarden aankopen. Een dergelijke strategie - die binnen veel pensioenfondsen wordt gehanteerd - leidt er dan dus toe dat als aandelenmarkten teruglopen vastrentende waarden worden verkocht en aandelen worden aangekocht. Met andere woorden, als het minder gaat met de financiële 
positie van het fonds in die zin dat dekkingsgraden teruglopen dan gaan we het risico verder opvoeren. En dat is - om het voorzichtig uit te drukken - toch ietwat tegenstrijdig. Maar ook het omgekeerde komt enigszins vreemd over. Als aandelenmarkten goed presteren, dan gaan we aandelen verkopen. Echter vanuit risico-optiek nemen de stootkussens toe en zou er meer risico gelopen mogen worden. Dus ook hier werkt deze strategie enigszins verwarrend. Het gevolg was dat in de jaren negentig nogal eens creatief met constante mix strategieën werd omgegaan. Ofschoon een constante mix strategie vaste gewichten aan de relatieve omvang van beleggingsportefeuilles stelt, worden wel bandbreedtes gegeven waarbinnen deze gewichten zich dienen te bevinden. Dit impliceert dat aan het relatieve belang onder- en bovengrenzen worden gesteld. Vanuit risicooptiek zou een buy and hold beleid beter passen. Immers, binnen een dergelijke strategie wordt het belang in aandelen automatisch afgebouwd indien markten minder presteren en neemt het belang toe indien markten aantrekken. In tegenstelling tot de eerder gememoreerde constante mix strategie waarbinnen mean reversion centraal staat, gaat een buy and hold beleid uit van trending. Een dynamische beleggingsstrategie is een strategie waarbij het relatieve belang in aandelen afhangt van de dekkingsgraad. Deze strategie heeft zowel kenmerken van een constante mix strategie als van een buy and hold strategie. Een dergelijke strategie heeft een directe relatie met de financiële risicopositie van een pensioenfonds. Om die reden is naar mijn mening een dynamische beleggingsstrategie het best passend voor een pensioenfonds. Het rücksichtslos toepassen van een constante mix strategie kan bij een dalende aandelenmarkt een pensioenfonds in grote problemen brengen.

Vanuit de optiek van houdbaarheid van ons pensioenstelsel past in mijn perceptie een dynamisch beleggingsbeleid beter. Een constante mix strategie kan bij strikte doorvoer een pensioenfonds in forse financiële problemen brengen. Een buy and hold beleid laat de relatie tussen beleggingen en verplichtingen geheel los. Een dynamisch beleggingsbeleid, waarbij de relatieve samenstelling van de beleggingsportefeuille een directe relatie toont met de dekkingsgraad is vanuit ALM-optiek te prefereren. Het bevreemdt dat in de PVK-richtlijn geen uitwijding over het beleggingsbeleid in het algemeen en de relatieve samenstelling van de beleggingsportefeuille in het bijzonder plaatsvindt.

\section{Het vermogenswaarderingsbeleid}

Om fluctuaties in de beleggingen op te vangen zijn vermogensbuffers benodigd. Met name aandeelrendementen zijn aan flinke fluctuaties onderhevig en om die reden zouden in ieder geval voor deze beleggingscategorie buffers aangehouden moeten worden. Maar in welke mate? Is een constante buffer van $45 \%$ benodigd of dient dit percentage hoger c.q. lager te zijn? Ook hier kunnen we weer vanuit risico-optiek tot een voorstel komen. Indien het relatieve belang van aandelen binnen de beleggingsportefeuille fors is, zullen nadelige koerseffecten een 
redelijk grote invloed op de financiële positie hebben. In zo'n geval lijkt het wijs om een relatief grotere buffer te hanteren. Indien het belang in aandelen zeer beperkt is, is het de vraag of het zinvol is om substantiële buffers aan te houden. In een dergelijke situatie zou zelfs het verlies van de gehele aandelenportefeuille slechts een beperkte invloed op het rendement van de totale portefeuille - en daardoor op de risicopositie - hebben. De bepaling van de omvang van de vermogensbuffers en de systematiek met betrekking tot de wijze van vulling van deze buffers maakt dan ook onderdeel uit van de integrale aanpak zoals die binnen ALM wordt gehanteerd. Tot voor kort was het alom aanvaard dat koerswinsten richting de buffer stroomden. Waren de buffers vol, dan werden de additionele rendementen als gerealiseerde rendementen beschouwd en leidden dientengevolge tot een premieverlaging. Om wat beter te kunnen doorgronden hoe vermogensbuffer en premieberekening met elkaar verbonden zijn, is de onderstaande figuur toegevoegd.

Figuur 8 De opzet van het financiële kader

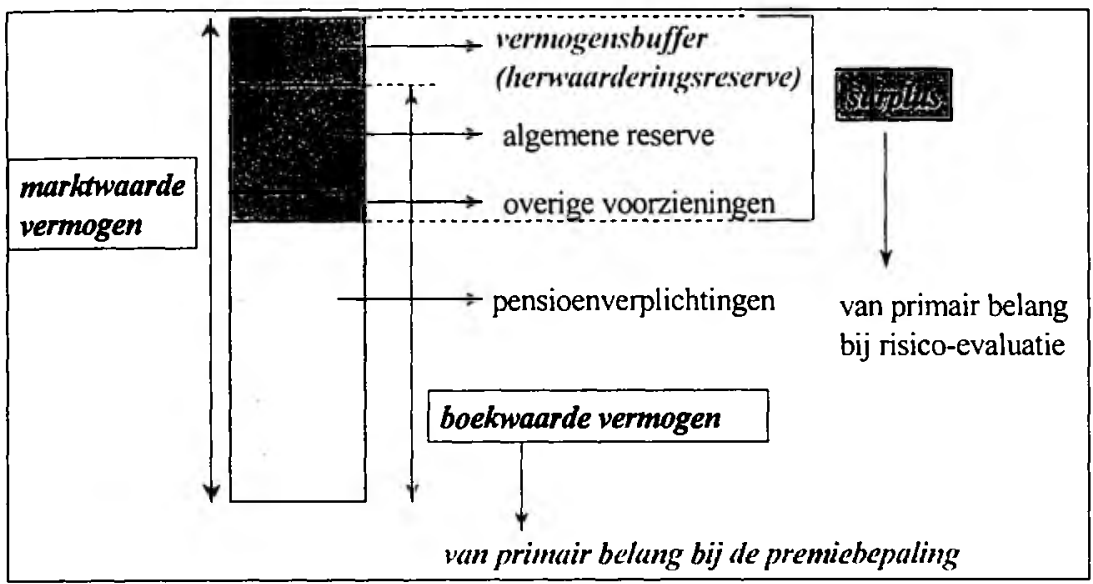

Nu zijn die buffers - die in het verleden (nagenoeg) vol waren - als gevolg van de enorme koersval in het recente jaar echter (nagenoeg) leeg. Indien we de systematiek hanteren dat alle koerswinsten naar de buffer vloeien totdat deze vol is - zoals de PVK (2002a) in haar schrijven aangeeft - houdt dat voor de premieberekening in dat gedurende een lange reeks van jaren slechts het dividendrendement als feitelijk rendement wordt bijgeschreven. Dat houdt in dat het boekvermogen, zoals gepresenteerd in het bovenstaande figuur slechts heel beperkt zal stijgen. Deze zeer beperkte stijging leidt - daar het boekvermogen de basis van de premieberekening vormt - tot relatief zeer hoge premievoeten. Vanuit die optiek bezien is het beleggen in aandelen dan ook niet aantrekkelijk 
en verschuift de aantrekkelijkheid van aandelen wel heel erg naar de lange termijn. Maar dan gaan we even terug naar de voorgaande paragraaf waarin de risicopremie van aandelen centraal stond. Zolang we nog de mening zijn toegedaan dat deze risicopremie een positieve waarde aanneemt blijft beleggen in aandelen aantrekkelijk. De risicopremie is de vergoeding die wordt verkregen voor het additionele risico dat verbonden is aan het houden van aandelen ten opzichte van vastrentende waarden. Het ligt dan ook veel meer in lijn met de achterliggende visie op de risicopremie om deze risicopremie te reserveren en naar de vermogensbuffer te brengen dan om de gehele koerswinst te reserveren. Willen aandelen voor pensioenfondsen - met name onder de huidige marktomstandigheden waar men naar verwachting al met forse premieverhogingen te kampen zal krijgen - een attractieve beleggingscategorie zijn, dan is het niet opportuun om het gehele koersrendement te reserveren. Het ligt dan veel meer voor de hand om de risicopremie naar de vermogensbuffers te laten vloeien. Door op deze wijze vermogensbuffers te vullen wordt bewerkstelligd dat aandelen vanuit premieoptiek tenminste gelijkwaardig zijn aan vastrentende waarden.

Verder verschaft de PVK richtlijnen ten aanzien van de minimumpositie van vermogensbuffers. Voor zakelijke waarden (aandelen en vastgoed) geldt dat de buffer zodanig in omvang dient te zijn dat een waardedaling dient te moeten kunnen worden opgevangen die 1) tenminste $40 \%$ lager ligt dan de hoogste stand van de benchmark in de afgelopen 48 maanden en 2) het fonds minimaal in staat moet zijn om een waardedaling op te vangen van $10 \%$ onder het laagste niveau van de benchmark in de afgelopen 12 maanden. Voor beleggingen in vastrentende waarden geldt dat bij een marktrente van $4 \%$ men over een buffer van tenminste $10 \%$ van de waarde van die beleggingen dient te beschikken en bij een marktrente van $6 \%$ of meer geen buffer meer aanwezig hoeft te zijn. Bij tussenliggende marktrentes dient de buffer naar rato te worden vastgesteld. De bepaling van de benodigde omvang van de vermogensbuffers is in de optiek van de PVK een geïsoleerde beslissing die alleen van de hoogte van de benchmark afhangt. Dit lijkt mij echter niet de juiste aanpak. De omvang van de vermogensbuffers dient zodanig te zijn, dat zij in combinatie met de inzet van de andere beleidsinstrumenten leidt tot een risicoprofiel dat in lijn ligt met datgene dat door de PVK wordt aangedragen. Hiervoor is ALM ontwikkeld.

Het geheel overziend moet gesteld worden dat het doorschuiven van de gehele koerswinst naar de vermogensbuffer de beleggingscategorie aandelen - in ieder geval op de korte termijn - onaantrekkelijk maakt, daar waar deze beleggingscategorie zeer relevant is om ook naar de toekomst toe pensioenen betaalbaar te houden. Het verdient dan ook aanbeveling om niet dit gehele koersrendement, maar slechts een gedeelte - bijvoorbeeld voor zover overeenkomend met de risicopremie - naar deze buffers te brengen. Wordt niet voor deze optie gekozen dan rest pensioenfondsen niet veel anders dan het belang in aandelen af te 
bouwen. Hierdoor zullen relatief zeer hoge premievoeten resulteren. Immers, er is geen of slechts zeer beperkte premiekorting meer mogelijk als gevolg van het achterblijven van beleggingsrendementen. Ook de vraag in hoeverre er geïndexeerd kan worden is dan relevant. Immers in het huidige stelsel van pensioenberekeningen waarbij uitgegaan wordt van een rekenrente van $4 \%$ zou bij een portefeuille die volledig uit vastrentende waarden bestaat slechts $1.5 \%$ aan indexatieruimte bestaan. Dit zal veelal onvoldoende zijn om volledig te kunnen indexeren. De opzet van de PVK, namelijk een zeker en betaalbaar pensioen staat op gespannen voet met de door de PVK ingezette beleidsregels". Aanpassing van de richtlijnen ten aanzien van het vullen van de vermogenbuffers, bijvoorbeeld in de bovenstaande richting, is dan ook gewenst.

\section{Het premie- en indexatiebeleid}

In het vorenstaande stond het beleggingsbeleid centraal. Naast beleggingsinkomsten zijn er premie-inkomsten. De benodigde hoogte van de premievoet oftewel het premiepercentage wordt bepaald aan de hand van de financiële positie enerzijds en de waarde van de opgebouwde rechten (vpv) en de streefdekkingsgraad anderzijds. Uit de notitie van de PVK is te lezen dat additioneel aan de voorziening pensioenverplichtingen een reserve van $5 \%$ voor algemene risico's dient te worden aangehouden. Deze 5\%-opslag is met name bedoeld om de overschatting van sterftekansen en daarmee de onderschatting van de waarde van de vpv op te vangen. Bezien we tabel 7 waarbinnen de financiële effecten van een gewijzigd sterfteverloop werden beschreven, dan is een dergelijke opslag niet irreëel.

Naast de op de voorgaande wijze bepaalde theoretische bijdrage dient de feitelijke bijdrage te worden onderscheiden. De feitelijke hoogte van de premievoet hangt af van de invulling van het premiebeleid. Nagenoeg alle pensioenfondsen leggen de maximale mutatie van de premievoet aan banden. Dat wil zeggen dat er afhankelijk van de feitelijke dekking wordt aangegeven wat de maximale verandering in die premievoet mag zijn.

De richtlijnen van de PVK zijn duidelijk. Indien er sprake is van een vermogenstekort (dat wil zeggen dat de dekkingsgraad onder de $100 \%{ }^{12}$ ligt) dienen er directe maatregelen genomen te worden. Zo dient er binnen drie maanden een herstelplan te worden overlegd dat zodanig van opzet is dat binnen één jaar een dekkingsgraad van $100 \%$ wordt bereikt. Dat brengt mij op een niet onbelangrijk

\footnotetext{
${ }^{11}$ Men zou zich de vraag kunnen stellen op welke wijze deze vermogensbuffers in het verleden dan zijn opgebouwd. Een aangepast waarderingsbeleid is de oorzaak van het ontstaan van buffers geweest. Daar waar in het verleden aandelen en vastrentende waarden werden gewaardeerd op historische aanschafwaarde c.q. op aflossingswaarde is in de negentiger jaren de overstap gemaakt naar waardering van beleggingen op marktwaarde. Daar deze marktwaarde zowel voor aandelen als vastrentende waarden veel hoger lag dan de aanschafwaarde en men geen verschuivingen als gevolg van waardering in de bepaling van de premievoet wilde, werd de meerwaarde als gevolg van marktwaardewaardering als buffer geactiveerd. Ziedaar de historie van het vullen van de vermogensbuffer.

${ }^{12}$ Deze $100 \%$ voorziening bevat de eerder genoemde reserve algemene risico's.
} 
punt en dat is de sturingskracht van de premie. Deze is veelal zeer beperkt. De oorzaak daarvan is vergrijzing. Veel pensioenfondsen kennen een vergrijzingsgraad van 5 of meer. De vergrijzingsgraad is hierbij gedefinieerd als de ratio die voortvloeit uit de deling waarbij de teller gelijk is aan de vpv en de noemer aan de bijdragegrondslag. Een factor 5 impliceert dat een onverwachte stijging van de voorziening met $1 \%$ - indien direct gecompenseerd door premiebetaling gelijk is aan een premieverhoging van 5\%-punt. Bij een dekkingsgraad van $95 \%$ dient $5 \%$ aan vermogen te worden gecompenseerd. Dit brengt een verhoging van de premievoet van 25\%-punt met zich mee. Premievoeten van rond de $40 \%$ zouden dan resulteren. Dat is niet realistisch. In een dergelijke situatie is het verstrekken van aanvullende middelen vanuit de organisatie de enige mogelijkheid om terug te keren naar het gewenste niveau van $100 \%$. Helaas is er een relatie tussen terugval in beleggingsrendementen en de economische toestand in de wereld. Terugval in beleggingsrendementen komt voort uit tegenvallende bedrijfsresultaten. Dus net wanneer het financieel minder gaat met bedrijven dienen er aanvullende middelen aan het pensioenfonds ter beschikking gesteld te worden en dat is geen sinecure. Een alternatief is het korten van bestaande rechten op een zodanige wijze dat als gevolg van deze korting er een vpv resulteert die overeenkomt met een dekkingsgraad van 100\%. Een andere mogelijkheid behelst aanpassing van de pensioenregeling, zodanig dat kosten en baten naar de toekomst toe weer met elkaar in overeenstemming zijn. Een alternatief zou kunnen zijn het opstellen van een financieringsplan waarbij binnen een termijn van bijvoorbeeld drie jaar het vermogen weer op niveau wordt gebracht. Van belang hierbij is wel dat de financiële positie niet verder achteruit loopt als gevolg van onvoldoende financiering. Dat houdt in dat de actuarieel benodigde premievoet ook daadwerkelijk wordt geheven. Zelfs het ophogen van de vigerende premievoet naar de actuarieel benodigde premievoet ${ }^{13}$ is voor veel fondsen immers al een forse stap en komt vaak uit op een verdubbeling van de vigerende premievoet. Toch is heffing van de actuarieel benodigde premievoet geen onrealistische eis. Immers, indien in een situatie van onderdekking een premie lager dan de actuarieel benodigde premie wordt geheven, dan leidt dit tot een verdere verslechtering van de vermogenspositie hetgeen uiteraard niet wenselijk is. De vraag is evenwel wat een dergelijke ingrijpende stijging van de premievoet tot gevolg heeft. Daar zowel werknemers als werkgevers volgens een in het reglement beschreven verdeling premie afdragen impliceert premieverhoging normaliter een directe verlaging van de koopkracht van werknemers. Indien binnen de CAO-onderhandeling compensatie voor deze teruggang wordt geëist en ingewilligd komen we in een neerwaartse spiraal terecht waarbij als gevolg van de loonontwikkeling de pensioenkosten wederom

\footnotetext{
${ }^{13}$ De actuarieel benodigde premievoet is hierbij gedefinieerd als de premievoet dic benodigd is om de in enig jaar opgebouwde pensioenrechten te dekken. Additionele indexatielasten dienen gefinancierd te worden uit additionele beleggingsrendementen. Voor een eindloonsysteem impliceert dit dat de backservicelasten voor actieve deelnemers in deze premievoet begrepen zijn. Voor de premievoet behorende bij een geündexeerd middelloonsysteem ontbreken deze lasten.
} 
verder toenemen, hetgeen een verdere verhoging van de actuarieel benodigde premie tot gevolg heeft. Dit kan alleen maar eindigen met het failliet van ons pensioenstelsel. Loonmatiging is - hoe vervelend in een dergelijke situatie dit ook is - dan ook een eerste vereiste om het pensioenstelsel overeind te houden. Verder mag ook van de niet-actiefdeelgerechtigden een offer verwacht worden in de vorm van voorwaardelijke indexatie. Daar waar solidariteit de pijler is van ons pensioenstelsel is het niet redelijk alleen de actieven met koopkrachtverlies op te zadelen. Ook de overige deelnemers zullen hun bijdrage moeten leveren. Voorwaardelijke indexatie is in een dergelijke situatie dan ook op z'n plaats. Een evenwichtige daling van de koopkracht voor alle deelgerechtigden zou dan ook het centrale thema moeten zijn bij het uitwerken van financieringsscenario's.

\section{Conclusie}

Ik heb getracht uiteen te zetten op welke fundamenten de waardebepaling van pensioenen berust. Hierbij heb ik willen aantonen dat aan deze fundamenten nogal wat haken en ogen zitten. Uitgangspunten die heden ten dage als triviaal worden beschouwd hebben een veel diepere achtergrond en dienen tegen deze achtergrond te worden geëvalueerd. Ook heb ik getracht aan te geven langs welke weg toekomstscenario's kunnen worden geconstrueerd. Op basis van deze toekomstscenario's kan evaluatie van het pensioenfonds als geheel binnen een ALM-context plaatsvinden. Deze evaluatie leidt vervolgens tot beleidsaanbevelingen, passend binnen de door het pensioenfonds aangegeven kaders.

Indien we pensioenfondsen mogen vergelijken met een mammoettanker, dan heb ik willen laten zien langs welke weg het vlottrekken en het wederom op koers krijgen van die tanker zou kunnen plaatsvinden. Een mammoettanker is geen speedboot. De manoeuvreerruimte van een tanker is beperkt. Indien uit koers geslagen kan alleen langs de weg van de geleidelijkheid de juiste richting weer hervonden worden. Richtlijnen zoals uitgevaardigd door de PVK, bedoeld om ook op de lange termijn pensioenen betaalbaar en zeker te houden, dienen met deze beperkte manoeuvreerruimte rekening te houden, want zouden anders averechts kunnen uitwerken. Indien de redelijkheid in dezen overschreden wordt, dan zal uiteindelijk een pensioenstelsel resulteren dat in zijn aard veel minder ambitieus is dan ons huidige stelsel, dan wel in een stelsel waarbij de belangrijkste risico's verschuiven van het pensioenfonds naar de individuele deelnemers. Mij lijkt dat een dergelijke ontwikkeling niet gewenst is. Hoewel pensioenfondsen thans in zwaar weer verkeren impliceert dit niet dat het pensioenstelsel als zodanig niet houdbaar zou zijn. Er zijn voldoende mogelijkheden om tot adequate bijsturing te komen. Wel vergt de huidige situatie behoedzaam manoeuvreren teneinde paniek te voorkomen. Het zou deze paniek kunnen zijn die, vertaald in allerlei geboden, een dermate grote druk op de 
financiering van ons pensioenstelsel zet dat daardoor de houdbaarheid van het pensioenstelsel in het gedrang komt.

Een laatste opmerking betreft het door de PVK aangedragen toetsingskader. Hierin ontbreekt het risicokader waarbinnen pensioenfondsen dienen te opereren. Het is nu net dit risicokader dat de randvoorwaarden bepaalt voor de invulling van de verschillende beleidsinstrumenten. Een geïsoleerde regelgeving waarin op een aantal facetten restricties worden gesteld past niet meer in de huidige wijze van risicomanagement. Herziening van de richtlijnen op dit punt wordt dan ook voorgesteld. De PVK zou een integrale ALM-aanpak moeten voorschrijven. Hierdoor worden pensioenfondsen in staat gesteld om binnen de daartoe aangedragen risicokaders hun eigen route te bepalen. Slechts langs deze weg is het mogelijk om op transparante wijze het beleid van pensioenfondsen te communiceren en te evalueren.

\section{Dankwoord}

Mijnheer de Rector Magnificus, dames en heren, dit brengt mij bij het laatste onderdeel van mijn rede: het dankwoord. Een bijzonder woord van dank wil ik richten tot mijn promotor Piet Moerland. Jij hebt op mij een onuitwisbare indruk gemaakt daar waar het gaat om integriteit en kunde. Jouw gestructureerde wijze van aanpak en opbouwende kritiek zijn voor mij een belangrijke leerschool geweest. Graag wil ik verder Willem Buijink noemen met wie ik vele jaren heb samengewerkt. Jij was degene die het initiatief tot de invulling van de nieuwe leerstoel Actuariële Wetenschappen hebt genomen en dat met veel energie, want dat kostte het, hebt doorgezet. Een woord van dank wil ik verder aan Franz Palm richten. Als dekaan heb jij je achter mijn kandidatuur geschaard en ervoor zorg gedragen dat ik hier vandaag in deze hoedanigheid sta. En uiteraard gaat mijn dank uit naar Hans Peters. Samen hebben wij de opleiding Asset Liability Management vormgegeven. Jij hebt daar veel tijd in geïnvesteerd en ik herinner mij onze gesprekken alsof ze pas gisteren gevoerd zijn. Met name jouw doortastende en toch Bourgondische aanpak staan mij daarbij helder voor de geest.

Een speciaal woord van dank gaat ook naar Bob Verdijk en Anita Pluymen. Jullie zorgen ervoor dat op kantoor alles op rolletjes loopt, waardoor er voor mij ruimte is om aan mijn hoogleraarschap invulling te geven.

Tot slot mijn familie, Mart en Marianne. Jullie interesse is voor mij altijd een enorme bron van inspiratie geweest. Ik ben jullie daar bijzonder dankbaar voor. En dan kom ik op het belangrijkste en dat is mijn gezin. Nicoline, Catherine en Wouter. Drie goudklompjes van onschatbare waarde. Hoe mooi een hoogleraarschap ook is, het is slechts een schim van dat wat jullie voor mij betekenen. Nog 
een speciaal woord wil ik richten tot Nicoline. Jouw spontane manier van leven leert me dat er nog zoveel andere mooie dingen in het leven zijn.

Daarmee ben ik aan het eind van mijn rede gekomen. Ik hoop dat mijn verhaal omtrent de houdbaarheidsdatum van ons pensioenstelsel $u$ niet te droevig gestemd heeft, want dat zou nergens voor nodig zijn. We bevinden ons thans in zwaar weer, niets meer en niets minder. Van schipbreuk is nog lang geen sprake. Er zijn voldoende mogelijkheden om ons pensioenstelsel ook op de langere termijn overeind te houden. Het is nu tijd voor een hapje en een drankje.

Ik heb gezegd. 


\section{Literatuur}

Blanchard, O.J. (1993), Movements in the equity premium, Brooking Papers on Economic Activity 2, 75-138

Bodie, Z., A. Kane and A.J. Marcus (1996), Investments, Irwin, 288

Briys, E and F. de Varenne (1997), On the Risk of Life Insurance Liabilities:

Debunking Some Common Piffalls, Journal of Risk and Insurance, 64, 4, 673-694

Cairns, A.J.G (2001), From Financial Economics to Fair Valuation, The Pension Institute, University of London, Discussion Paper PI-0109

Cochrane, J.H. (1994), Permanent and transitory components of GNP and stock prices, Quaterly Journal of Economics 109, 241-265

Diamond, P.A. (1999), What stock market returns to expect for the future? Center of Retirement Research at Boston College, September, Number 2

Dimson, E, P. Marsh and Mike Staunton (2002), Triumph of the Optimists, 101 Years of Global Investment Returns, Princeton University Press

Fama, E.F and K.R. French (1989), Business conditions and expected returns on stocks and bonds, Journal of Financial Economics, 25, 23-49

Fama, E.F. and K.R. French (2002), The equity premium, Journal of Finance, 57, 2, 637-659

Hazeu, C.A. (1998), Van Verzorgingsstaat naar Ondernemende Samenleving?, Een interpretatie van een kwart eeuw hervormingen in de sociale zekerheid, Liberaal Reveil, jaargang 39, nr.2, 70-79, april 1998

Heaton, J. and D. Lucas (1999), Stock prices and fundamentals, in Ben Bernanke and Julio Rotemberg, eds.:Macroeconomics Annual 1999 (National Bureau of Economics Research, MIT Press, Cambridge, MA)

Hertogh, M. (1992), Het Debat Staatspensioen, 1870-1930, Katholieke Universiteit Brabant: Sociale Zekerheidswetenschap, 17

Pensioen-\&Verzekeringskamer (PVK) (2002), Pensioenmonitor, niet-financiële gegevens pensioenfondsen, stand van zaken 1 januari 2002

Pensioen-\&Verzekeringskamer (PVK) (2002a), Uitgangspunten voor de financiële opzet en positie van pensioenfondsen, 30 september 2002, kenmerk 3.01/2002-8326

Siegel, J.J. (1999), The shrinking equity premium, Journal of Portfolio Management 26, 10-17

Shiller, R. (1989), Market Volatility, MIT Press, Cambridge, MA

Smink, M. and R. van der Meer (1998), De historische ontwikkelingen in Asset Liability Management, MAB, 4, 200-208

Sortino, F.A. and R. van der Meer (1991), Downside Risk: Capturing What's at Stake in Investment Situations, The Journal of Portfolio Management, 27-31 